\title{
أبو طالب الانباري-سيرته وآثاره العلمية
}

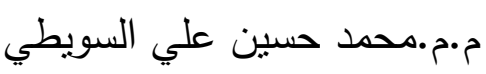

جامعة واسط/ كلية النريبة

المقدهة

يقف اليوم قصور الدراسات الأكاديمية والبحثية لأعلام الفكر الجعفري عاملاً أساسياً من عوامل الفال

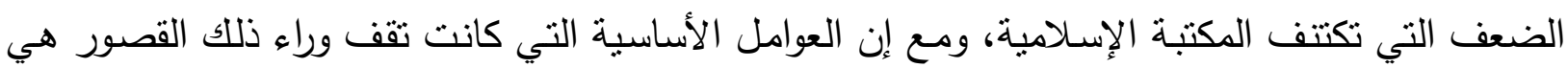

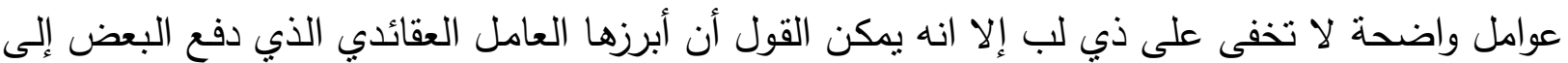

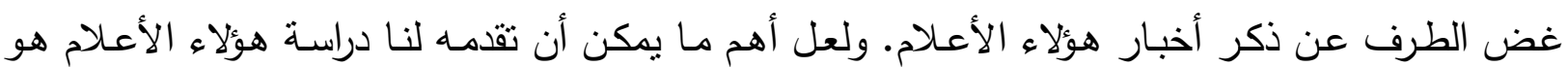

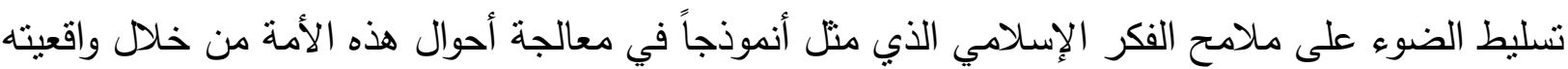

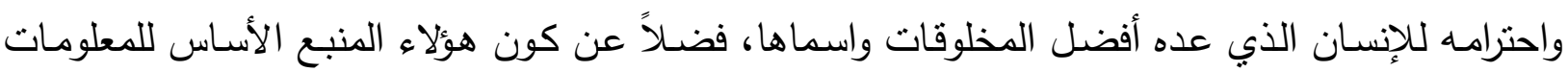

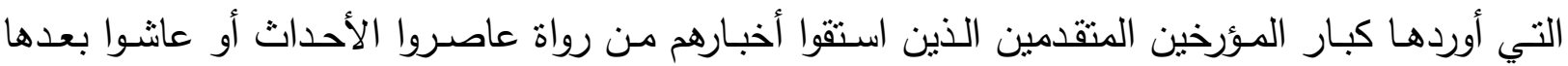

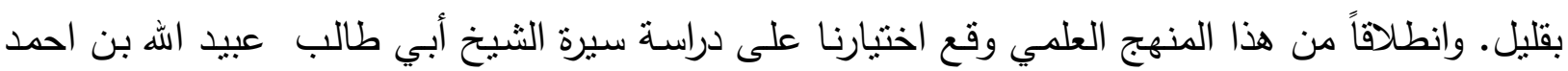

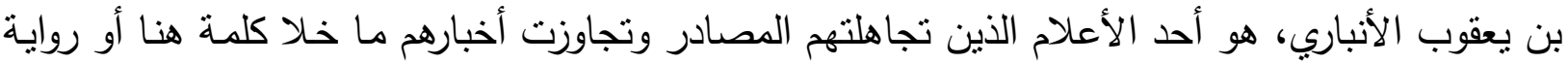

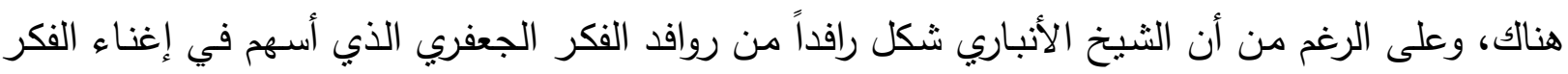

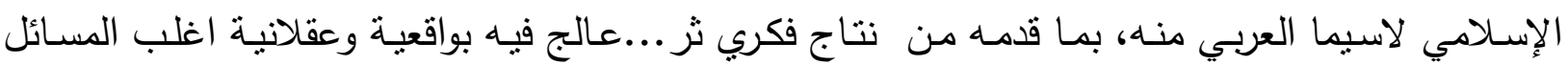

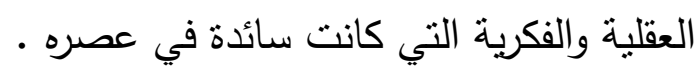

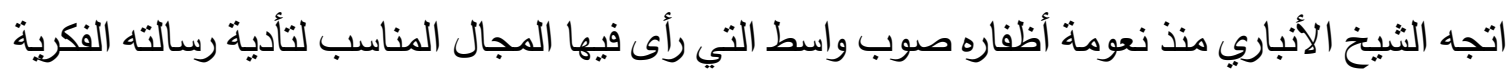

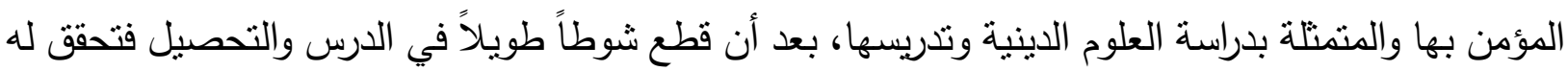

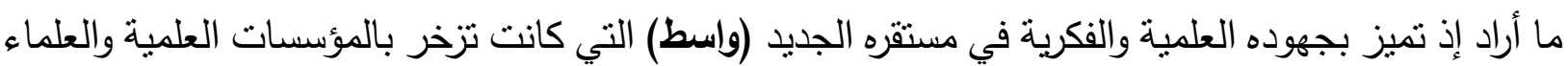

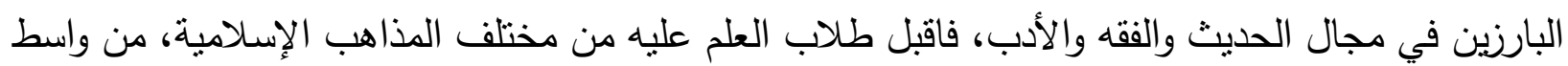

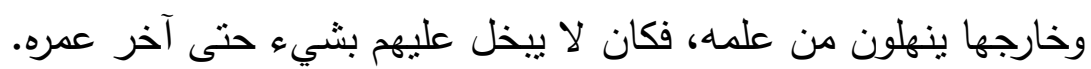

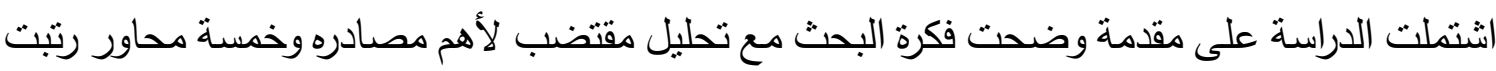
على النحو الآتي: ملامح عصره، موارد دراسته، ونسبه وسيرتها،ومؤلفاته، وآراء العلماء فيه، ثم الخاتمة، فضلاً عن قائمة المصادر.

ومن نافلة القول هنا إن المعلومات المتوافرة عن أخبار الثيخ أبي طالب الأنباري ومؤلفاته قليلة جداً إن الن الثان

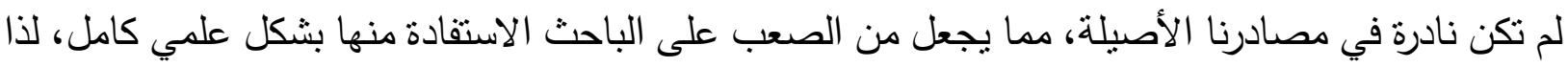

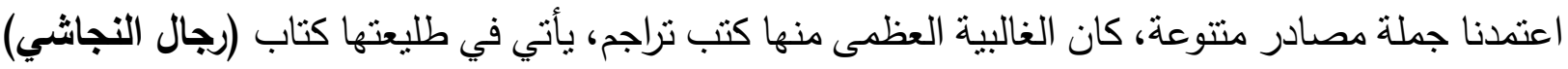

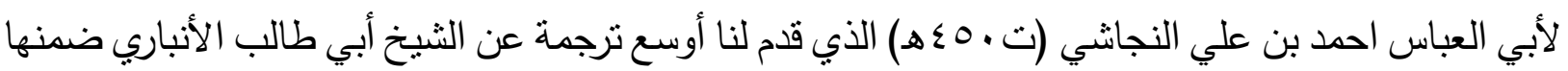

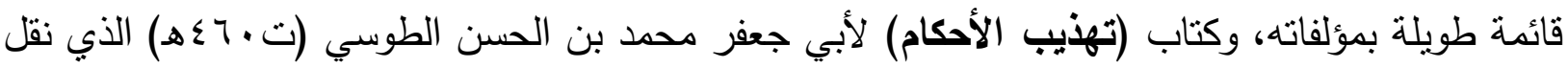

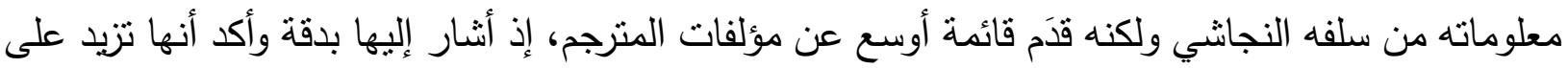


المائة والأربعين مصنفاً، لكنه اكتفى بإيراد عناوينها فقط دون أي تعليق، وكتاب (ذيل تاريخ بغداد) لمحب الدين محمد بن محمود المعروف بابن النجار (ت بـ 7هـ)، وعلى الرغم من انه من المصادر المتأخرة عن عهد الأنباري،

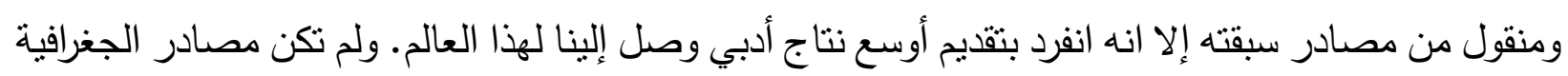

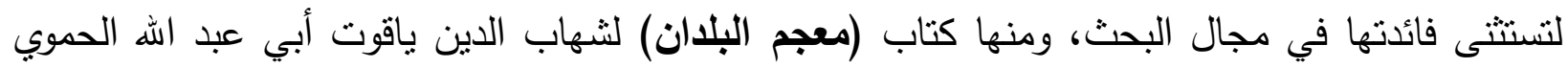

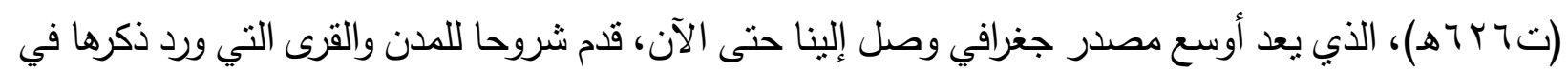

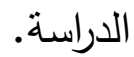

والى جانب المصادر الأصيلة وقفت المراجع الحديثة لتمد البحث بمعلومات ذات قيمة عن سيرة الثيخ

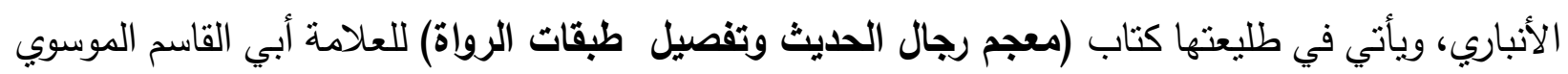
الخوئي الذي أسهم في تذليل بعض العقبات، كونه مختصاً بتاريخ رجال الحديث لا سيما الجعفرية منهم.

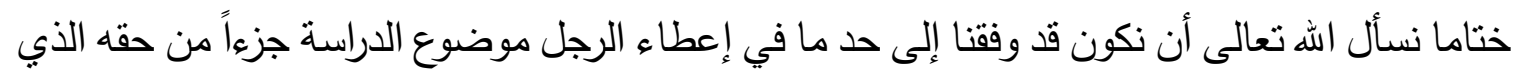

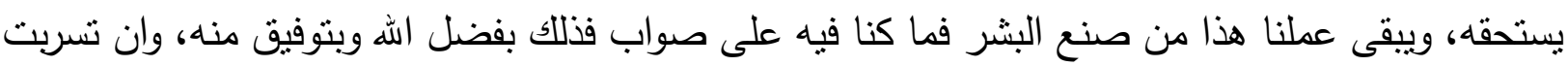

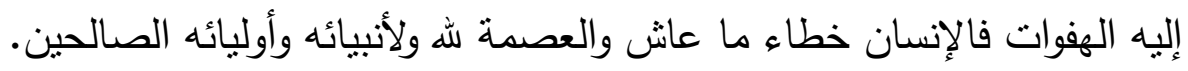
ملامح عصره: عاصر الثيخ أبو طالب الأنباري حقبة تاريخية حفلت بأحداث متتوعة ومهمة، إذ عاصر خلافة بني

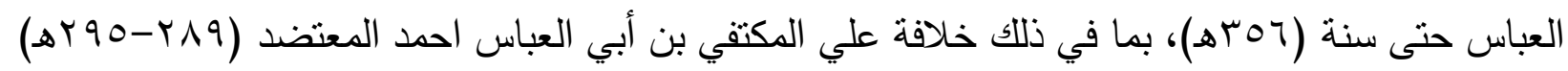

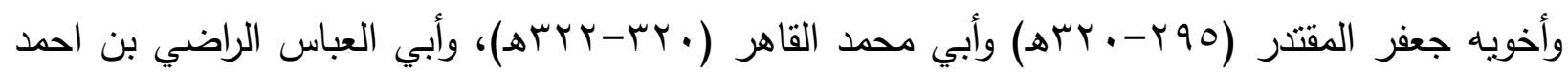

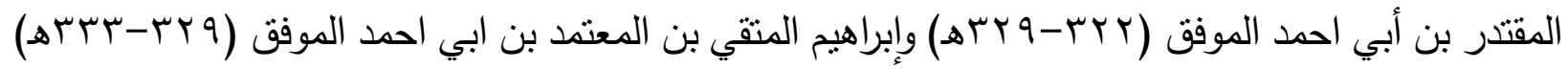

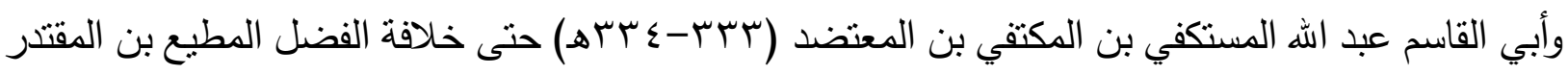

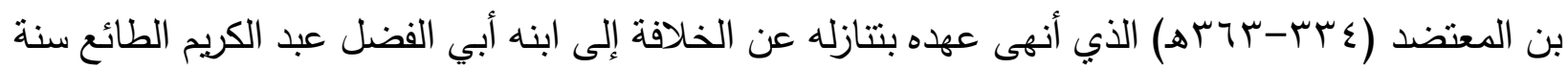

وكان الواقع السياسي للأمة الإسلامية طوال الحقبة التي عاصرها شيخنا يعاني ارتباكاً واضحاً، من أهم

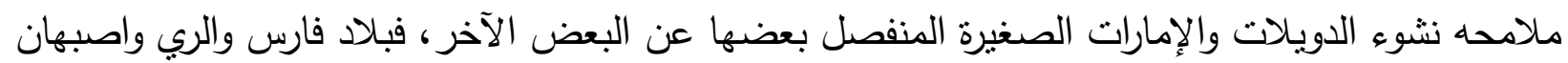

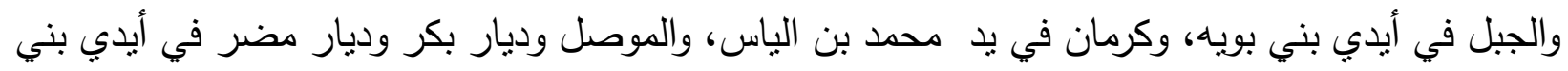

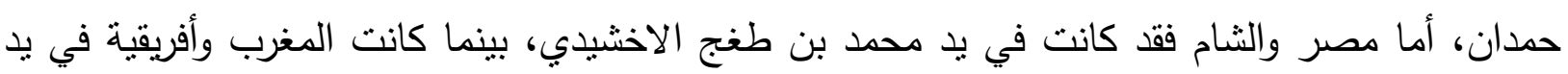

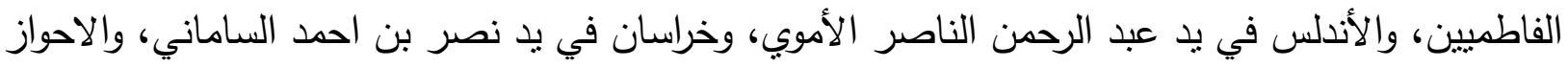

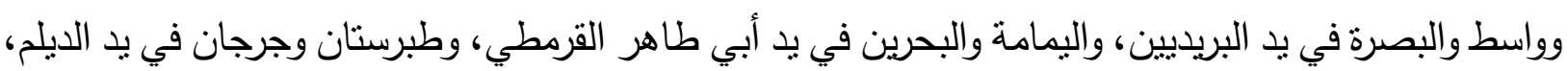

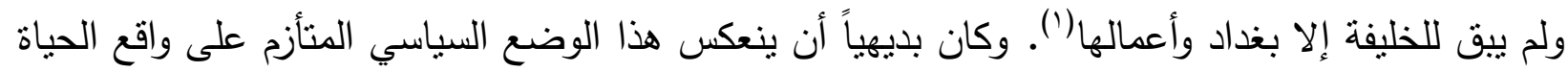
الاجتماعية آنذالك، فظهرت في بغداد مجاميع من اللصوص وقلاد وقاعي الطرق، سمتهم مصادرنا التاريخية بالعيارين

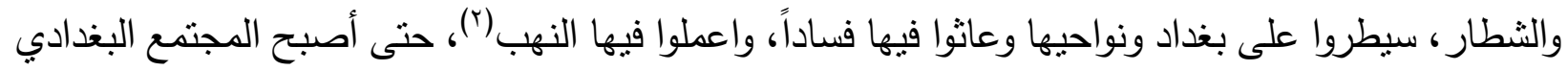


بمختلف طبقاته في خطر من جراء تحكم اللصوص في الثوارع والطرقات، فأغلقت الحمامات وتعطلت الأسواق والمساجد وغيرها من المؤسسات الخدمية(؟).

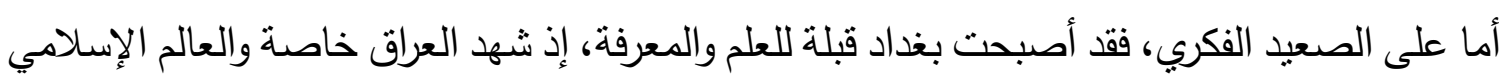
عامة نهضة علمية كبيرة نضجت فيها العلوم على اختلاف أنواعها وندت وازدهرت على الرغم من تدهور الحالة الكيا السياسية وضعف الخلافة وققدان السيطرة على الأقاليم والولايات(؛). وقد درس أحد الباحثين الحباة الفكرية في القرن الرابع الهجري، فوصل إلى نتيجة مفادها أن الفكر في

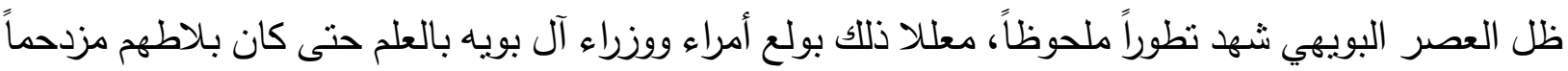
بأهل العلم والأدب الذين احتلوا مكانة راقية في الدولة البويهية(ْ)

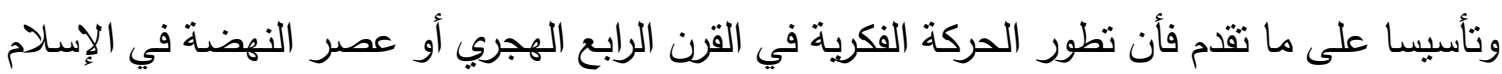

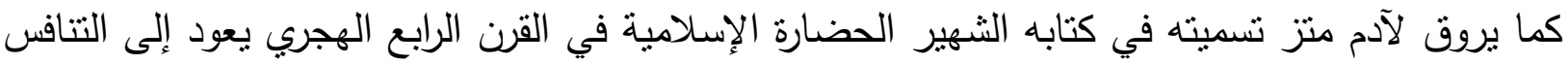

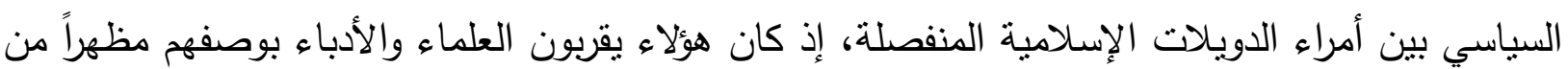
مظاهر الجاه والسلطان وحلية من حلى الزمان وواسطة لذيوع شهرتهم واكتمال سمعتهم في البلاد الإسلامية.

\section{هوارد أخباره:}

ترجم للثيخ أبي طالب الأنباري عدد من المؤرخين وعلماء الجرح والتعديل، وتباينت تلك المعلومات في وفرتها ودقتها، لا سيما أنها وردت في مصادر متتوعة منتاينة، في نوعيتها وفي زمن تدوينها أيضا، فجاء اغلبها

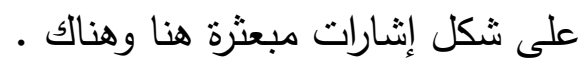

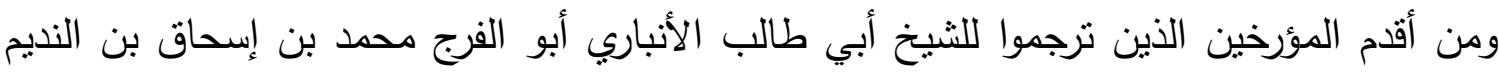

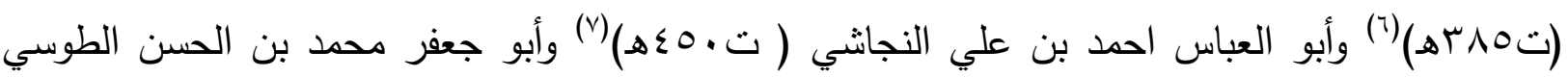

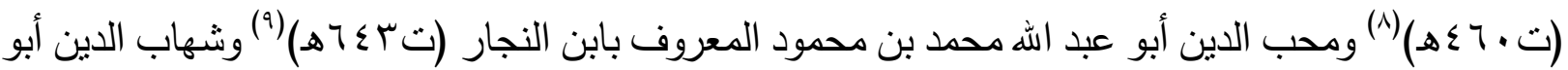

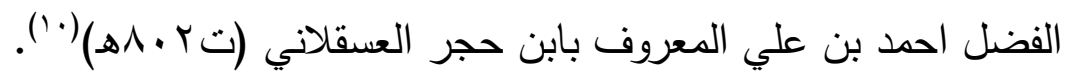

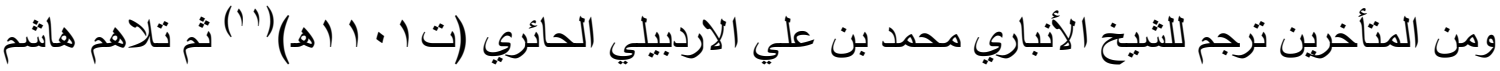

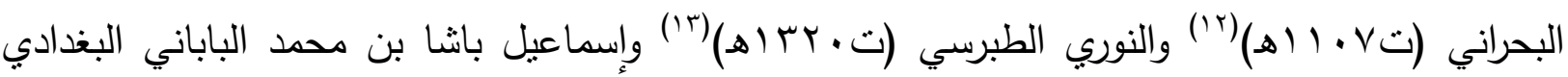

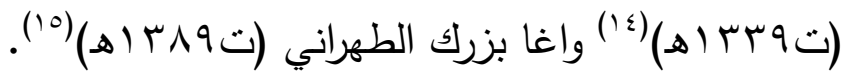
كما ترجم للثيخ أبي طالب عدد من العلماء والمؤرخين المحدثين، منهم العلامة أبو القاسم الموسوي

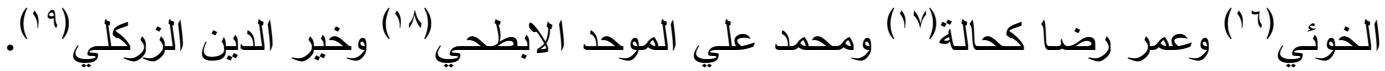

\section{(1) وسيرته:}

هو عبيد اله(·r) بن أبي زيد احمد بن يعقوب بن نصر ، أبو طالب الأنباري، نسبة إلى مدينة الأنبار (r)

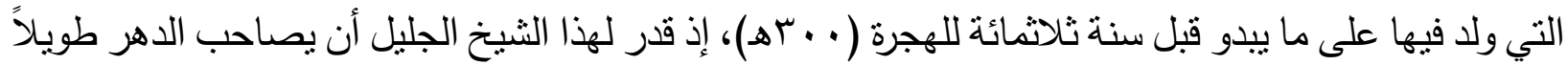
فلم يفنه حتى أصبح شيخا مسنا، فكانت وفاته بعد منتصف القرن الرابع الهجري كما سيمر بنا. انتقل برفقة والده من مقر ولادنه الأنبار بعمر مبكر إلى واسط التي وجد فيها ضالته العلمية المنشودة لكونها مركزاً علميا ذائع 
الصيت، فنهل العلم منذ زمن متقدم من عمره في مستقره الجديد (واسط)، حيث لازم علماءها وخاصة شيوخ الثيعة

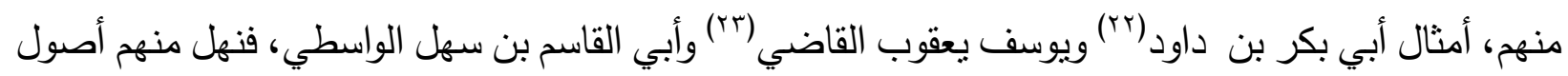

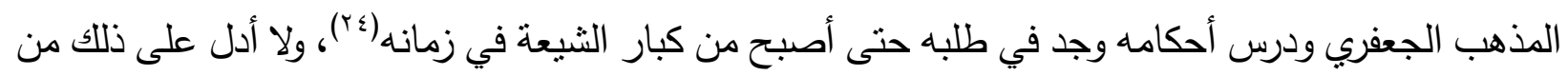

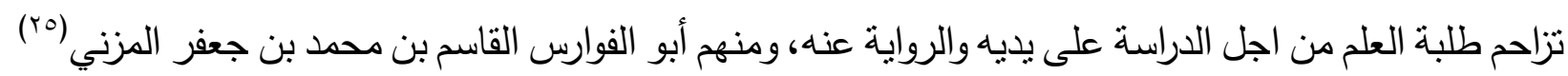

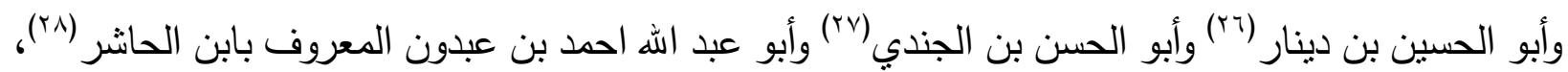

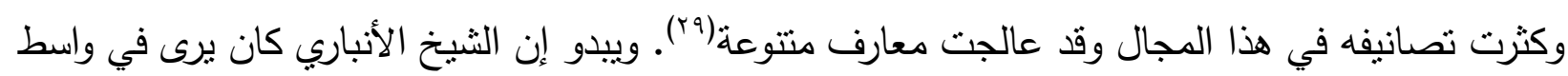

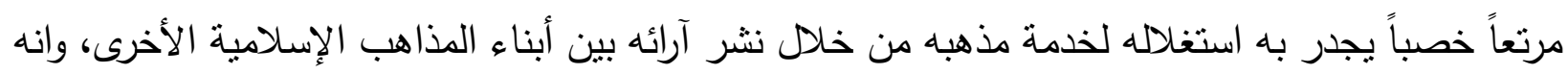
يستطيع جعل طلابه نواة لنشر التشيع في واسط.

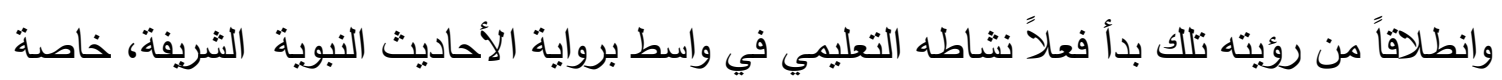

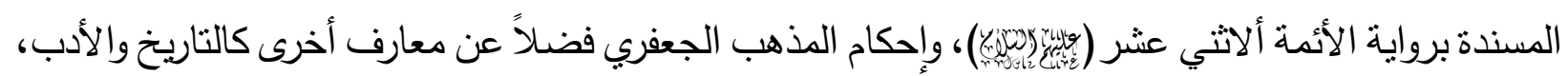
ولا شك أن مهمته تلاك كانت صعبة اكتنفتها المضايقات، لان معظم سكان واسط كانوا على مذهب أهل الهن السنة،

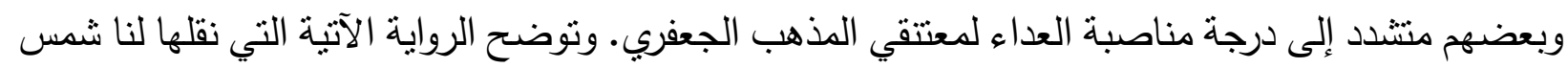

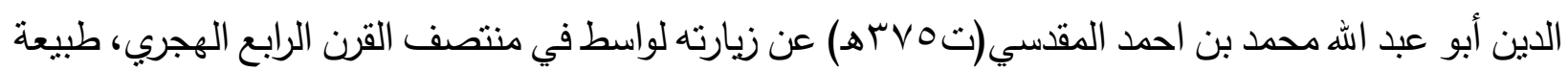

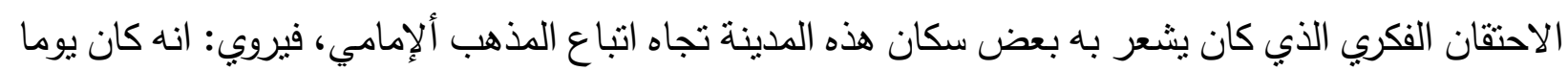

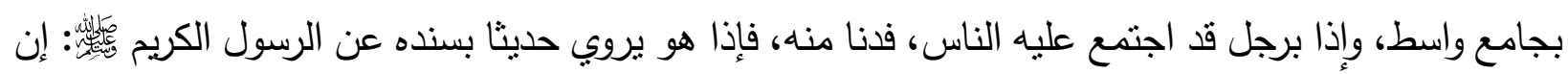

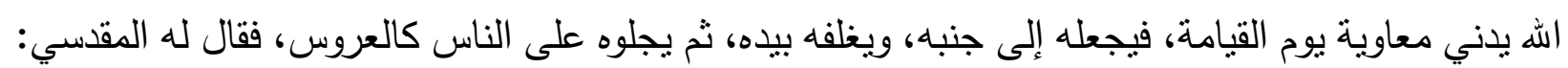
كذبت يا ضال: فقال: خذوا هذا الرافضي، فاقبل الناس عليه، فعرفه بعض الكتبة ودافعوا عنه (r.r).

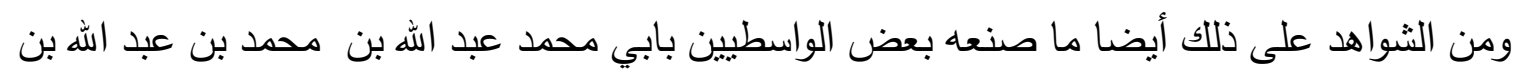

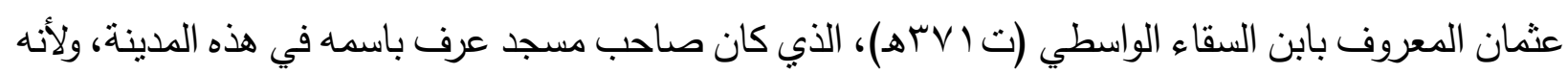

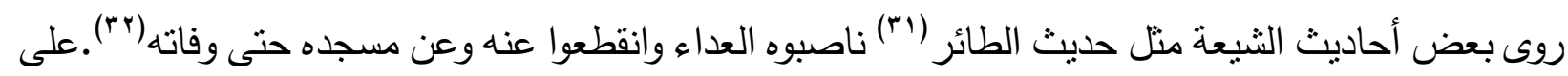
إن الثيخ أبا طالب الأنباري لم يستكن للظروف المحيطة به، بل قاومها بشكل سلمي حتى استطاع بأسلوبه

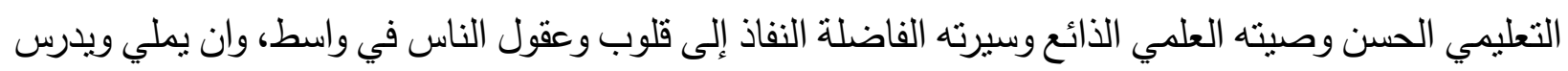
الدذهب الجعفري وإحكامه، ويكون له طلاباً ومريدين (َr). ولكن للضغوط الطائفية من قبل بعض سكان واسط التي ظلت تلاحق طلانيا ومرين الثيخ الأنباري من جهة، ورغبته

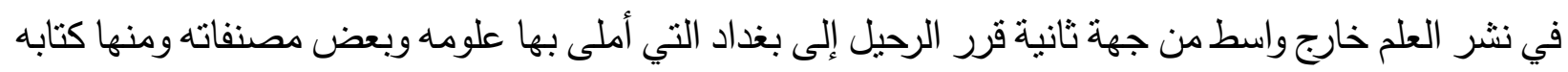
(الخط وإلقلم)، وكان ذلك في مجالس مشهورة ومعروفة بصبغتها الثيعية(؛ بـ").

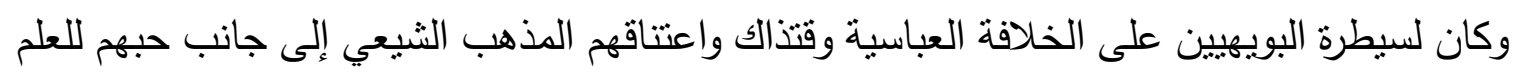
والسعي من اجل نشره أثثر في الحرية الني نالها الثيخ أبو طالب في سكناه الجديد ببغداد فمارس تعليم أحكام

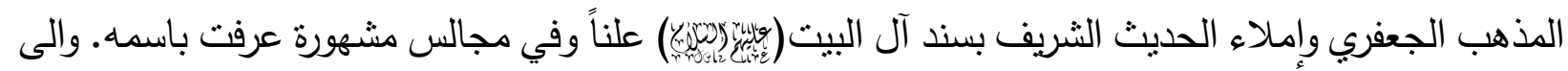

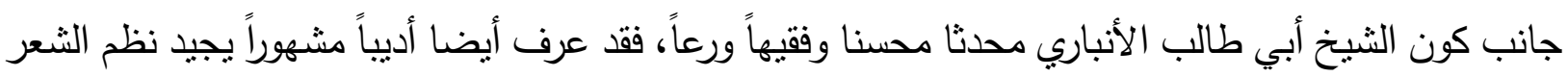


وروايته، ومعظم شعره في الوعظ والإرشاد والابتعاد عن زخرف الدنيا وملذاتها التي تشخط الخالق وتفسد المخلوق،

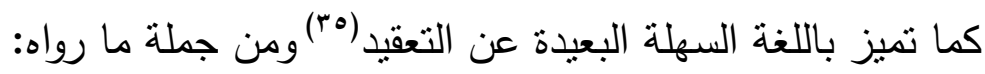

تذكرهم ما في سواهم من الفضـل

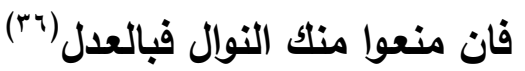

إذا ما مدحت الباخلين فإنمـا

وتهدي لهم غما طويلاً وحسرة

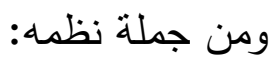

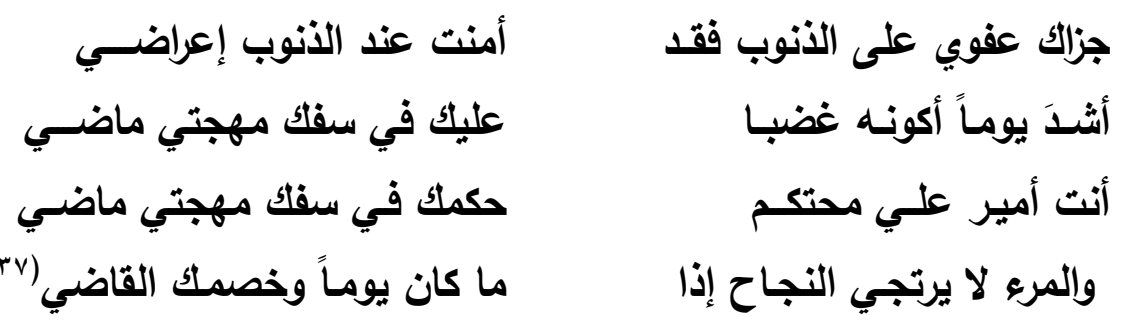

كما اسند إليه ابن النجار شعرا يجري غرضه في الغزل يقول فيه:

وجلَ عن واصف في الناس يحكيهِ

جَلت محاسنـه عن كل تثبيـه

سبحان خالقه سبحان باريـهِ

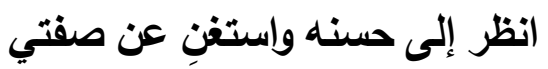

والأقحوان النضير النضر في فيسه

النرجس الغض والورد الجني لله

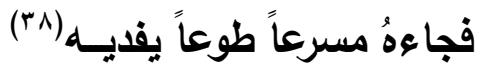

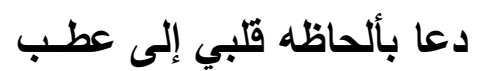

وبعد عمر طويل مليء بالعطاء العلمي، انتقل الثيخ أبو طالب الأنباري إلى جوار ربه بعد منتصف القرن الرابع

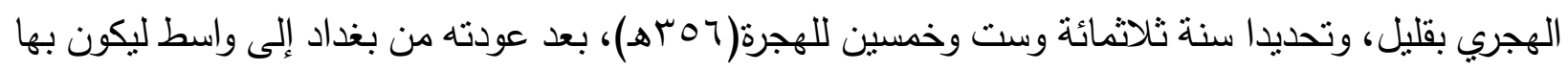

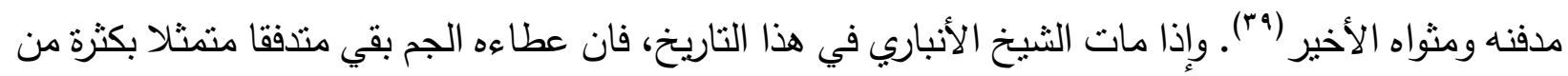

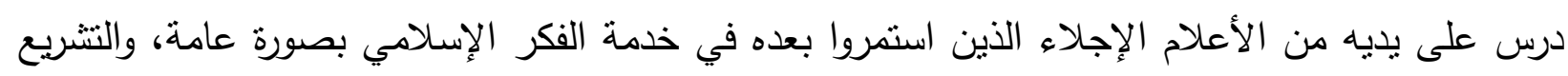

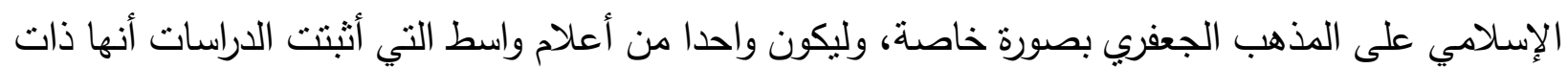
أثز فكري فاعل وبارز في التاريخ الإسلامي (·؛). 
كان الثيخ أبو طالب الأنباري من بين العلماء الذين صنفوا كتباً عدة، ولكن للأسف جميعها في عداد المفقودات حتى اليوم، ومن خلال المعلومات التي وصلت إلينا عن مؤلفات هذا الثيخ ينتين إن معظمها جاء النياء

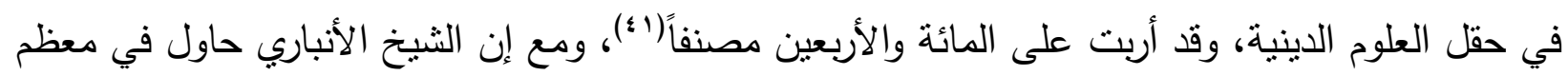

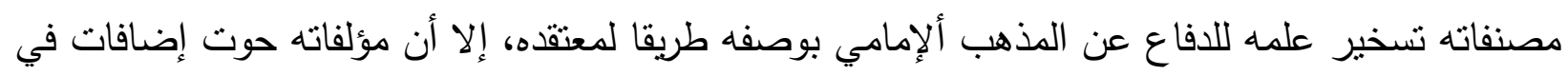

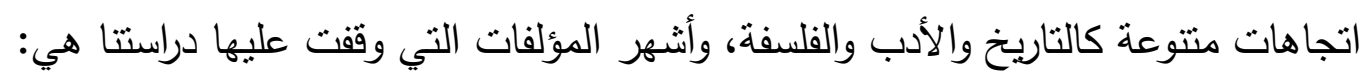

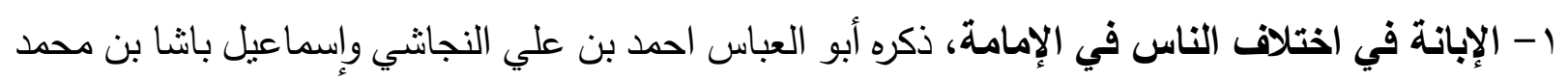

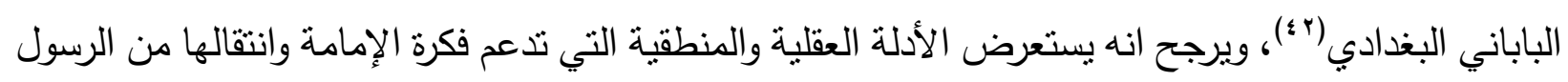

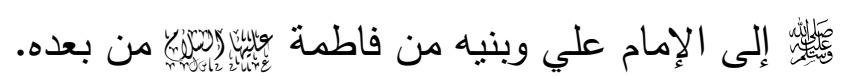

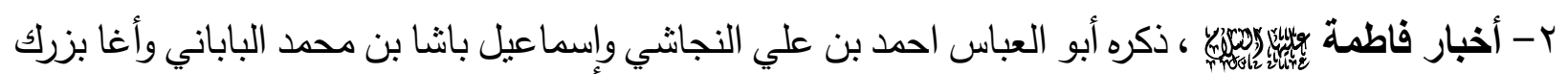

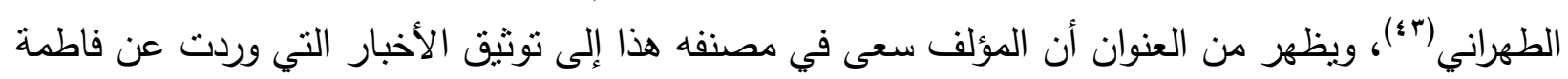

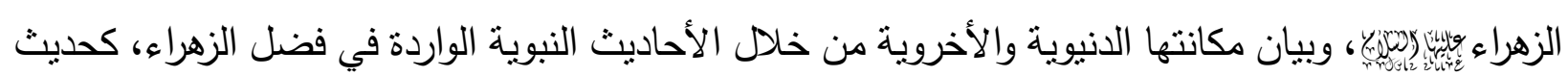

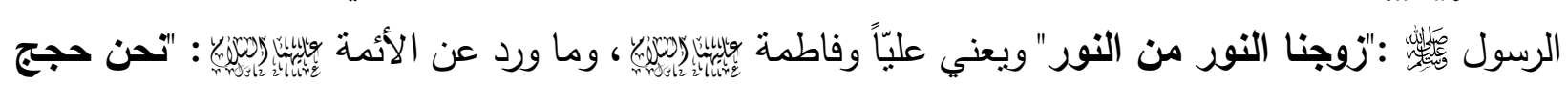

الله وفاطمة حجة الله علينا"(؛ ؛).

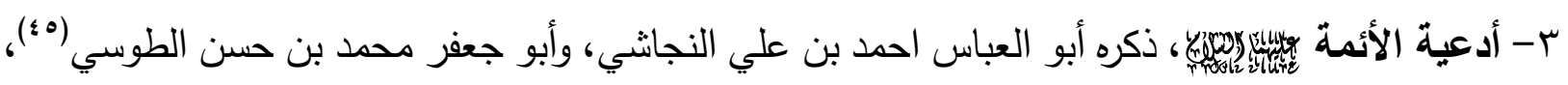

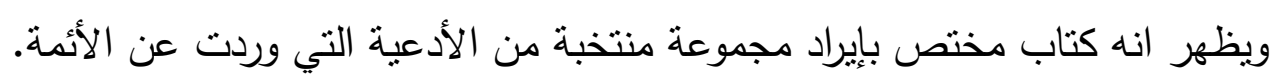

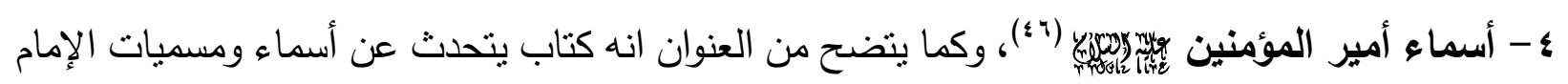

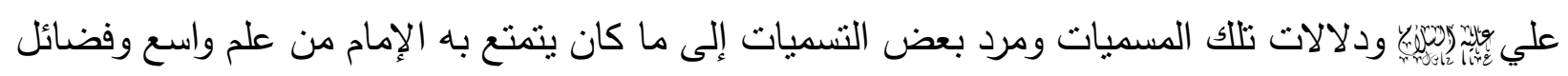
جمة.

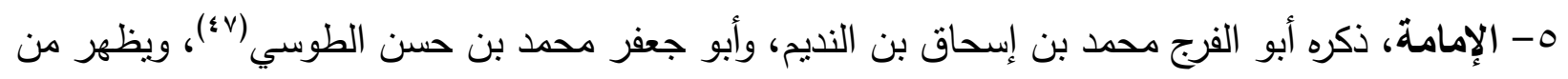

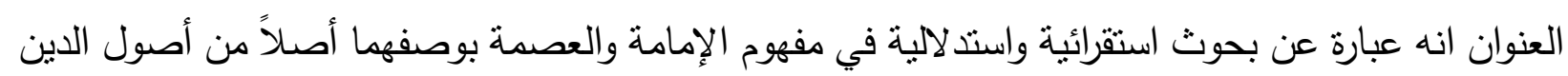

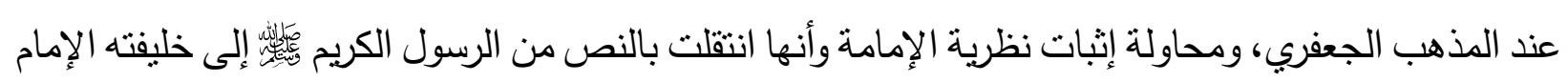

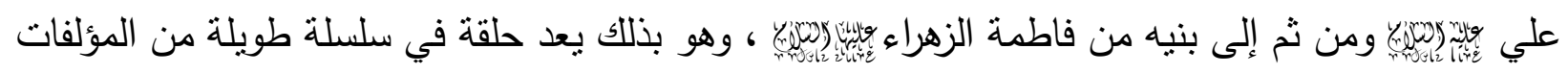
التي دأب علماء المذهب الجعفري على نسجها دون انقطاع في تأكيد نظرية الإمامة على ما سواها من نظريات التهاء

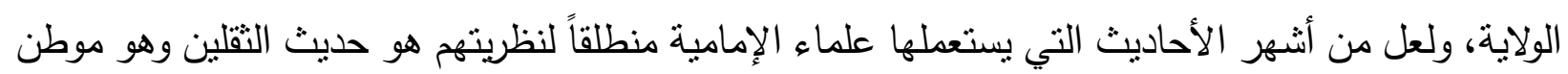

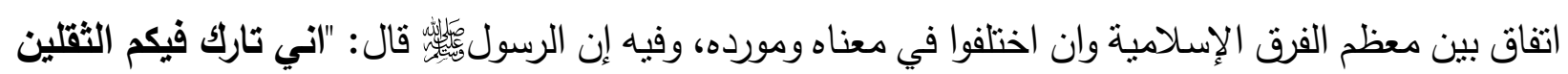

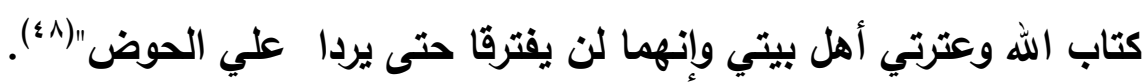

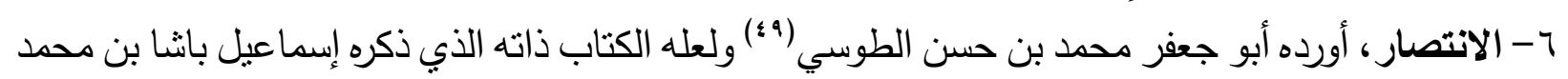

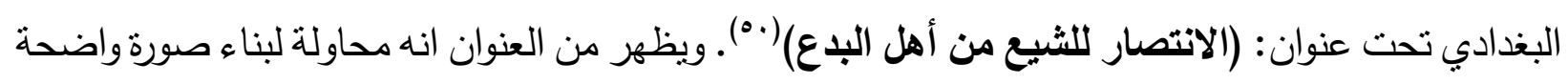


وصحيحة عن الدذهب الجعفري، واستلال وتفنيد الآراء الباطلة التي أوردها البعض في نشأة الدذه، وفي

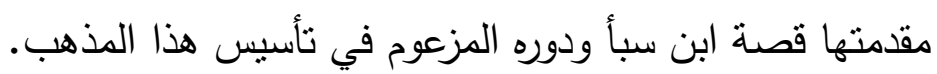

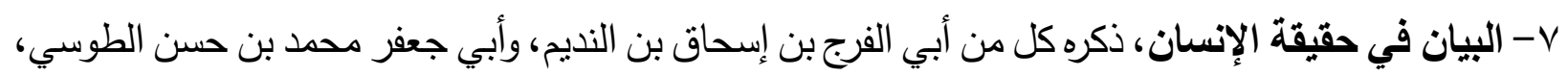

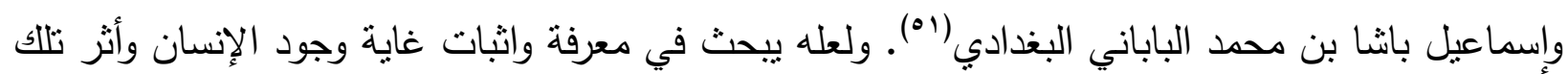

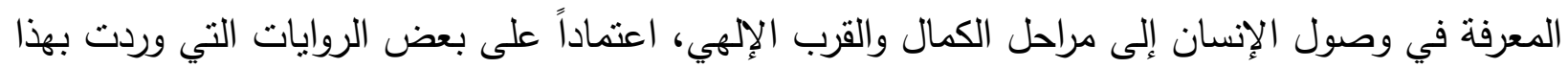

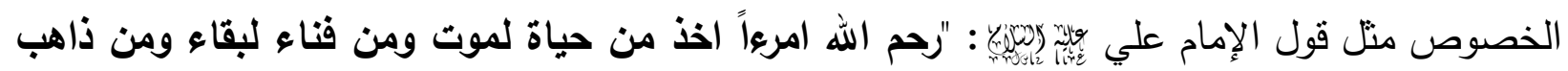

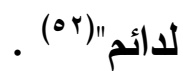

1 - التطهير ، ورد ذكره إلى جانب سابقه عند كل من أبي جعفر محمد بن حسن الطوسي وإسماعيل بانشا بن محمد الباباني البغدادي(هr). والمؤلف كما يتضح من العنوان أثنبه بالرسالة العملية التي ربما تتاولت باب التطبيق

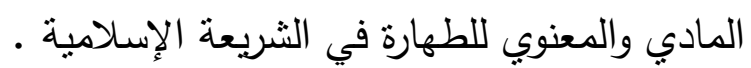

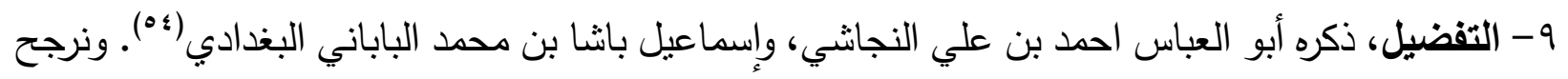

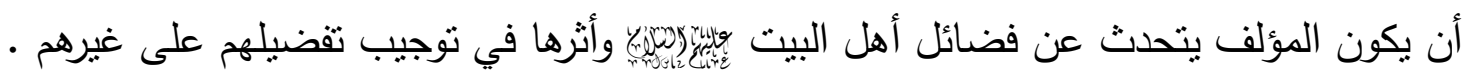

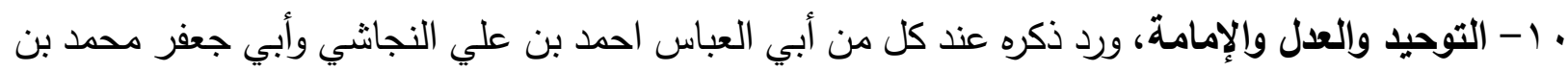

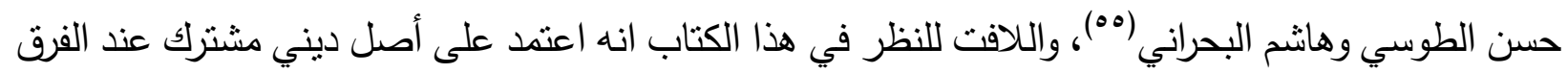

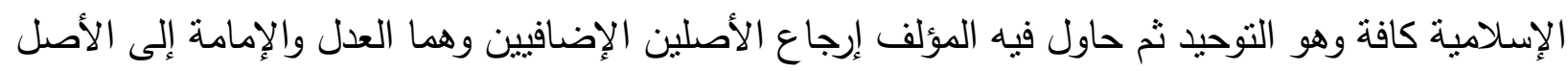

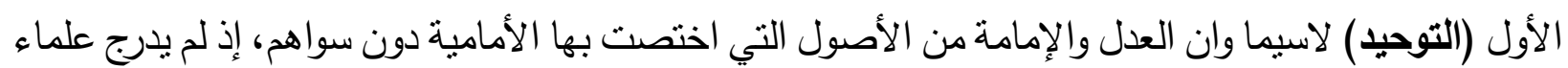
المذاهب الأخرى هذين الأصلين ضمن أصول الدين التي تتمنل عندهم في ثلاثة فقط هي:(التوحيد - النبوة المعاد) - الماد

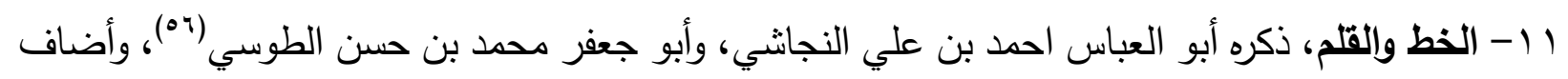

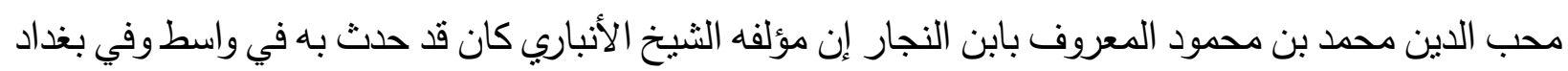

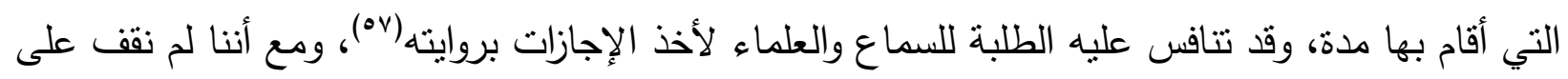

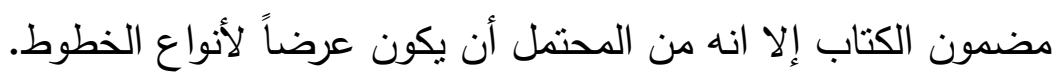
r ا - الثافي في علوم الدين، ذكره أبو جعفر محمد بن حسن الطوسي، وإسماعيل بانثا بن محمد الباباني البغدادي(^^)، واغلب الظن انه كتاب موسوعي يلتمس فيه المؤلف بعض المرامي في الدين الإسلامي ومواردها الثرعية. با - شرح الثمائل للترمذي، انفرد بذكره صاحب معجم المؤلفين(ه)، ويظهر انه بحث وتعليق في كتاب

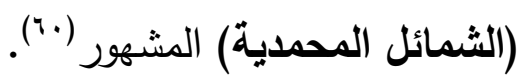
ع ا - الصفوة، أورده كل من أبي العباس احمد بن علي النجاثي وإسماعيل باشثا بن محمد الباباني البغدادي وأغا

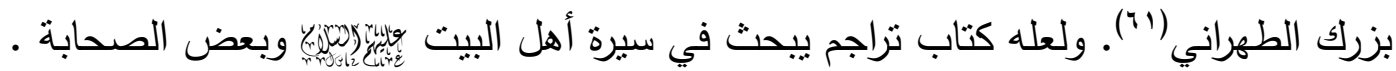


0 ا - طرق حديث أنت مني بمنزلة هارون من موسى، بلا شك هو مبحث آخر يستعرض فيه المؤلف كما يبدو

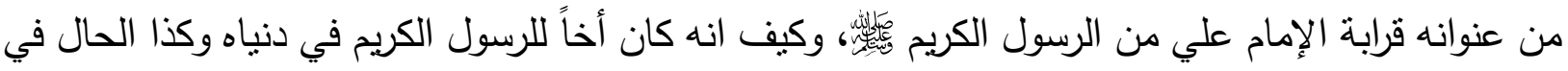

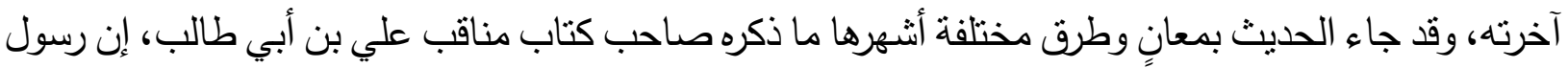

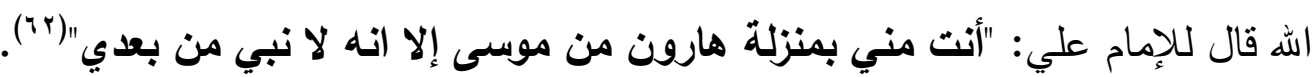

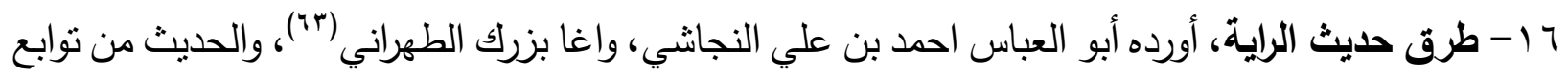

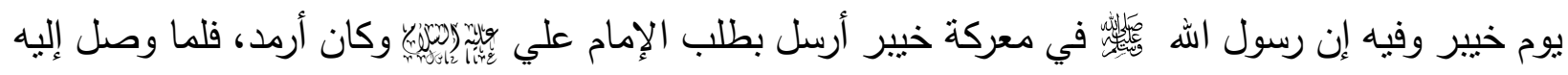

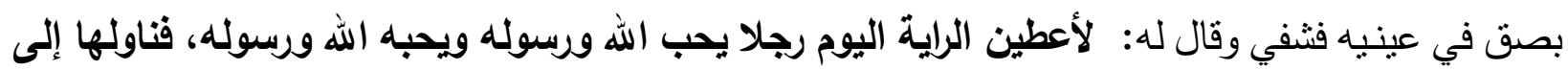

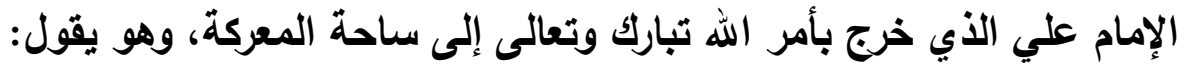
كليث غابات كريه المنظرة أنا الذي سمته أمي حيدرة

\section{أوفيكم بالصاع كيل السندرة}

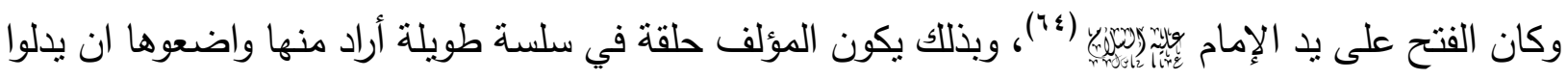
على أفضلية الإمام علي وتقديم الرسول إياه على من سواه، والحديث كما هو واضح يظهر بشكل جلي شجاعة لإنة

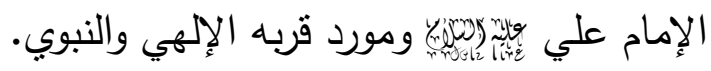
V V - طرق حديث الطائر، أورده أبو جعفر محمد بن حسن الطوسي، وأغا بزرك الطهراني(70). ويظهر من

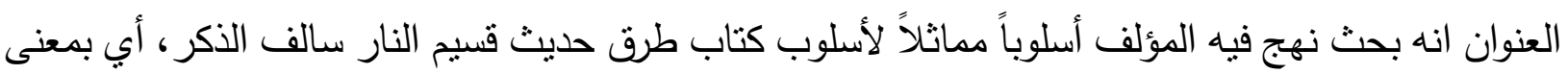

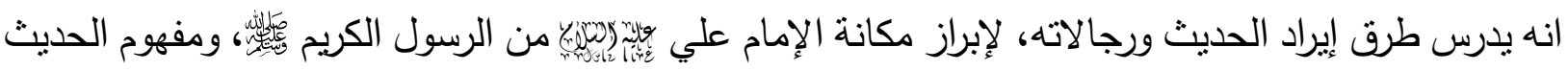

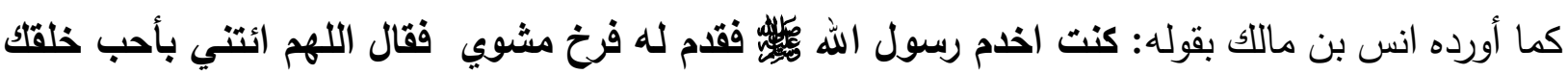

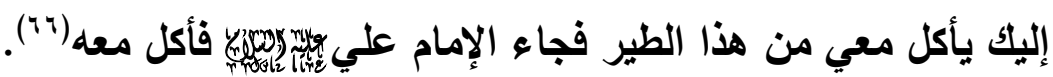

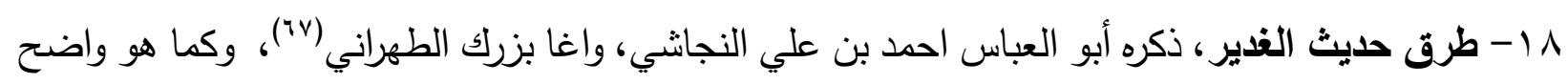

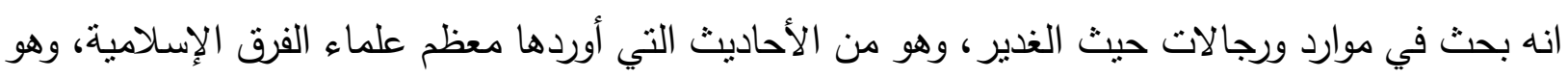

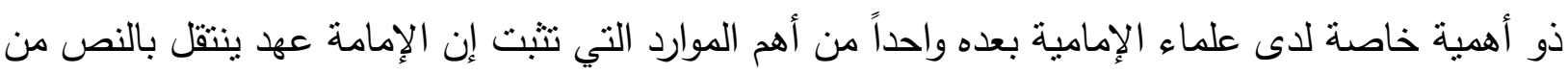

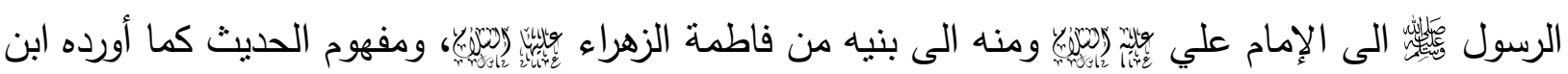

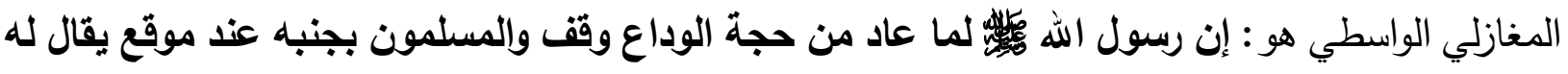

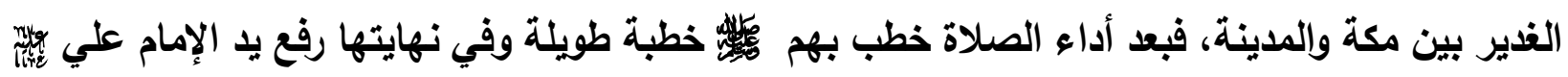

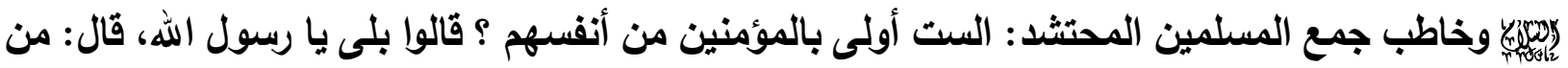

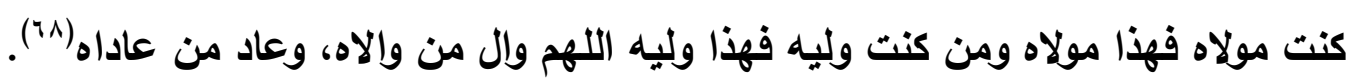

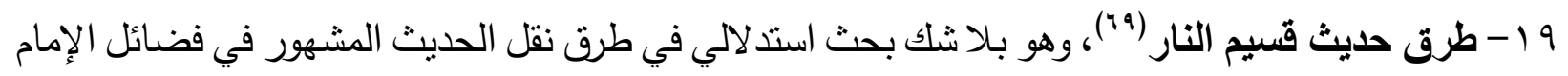
علي

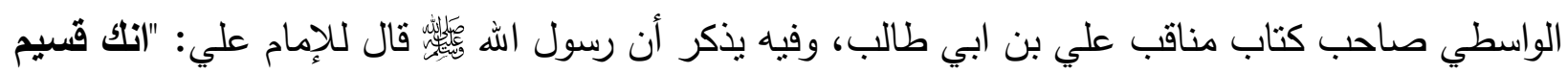


النار، وإنك تقرع باب الجنة وتلخلها بغير حساب"(v). ومما يظهر أن الثيخ الأنباري أراد الوقوف على صحة

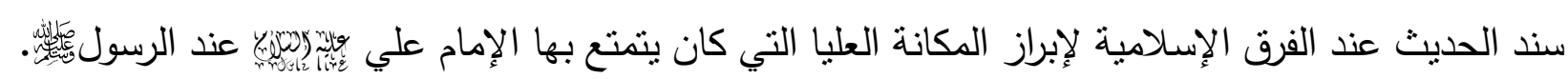

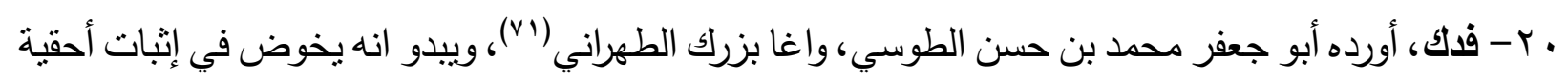

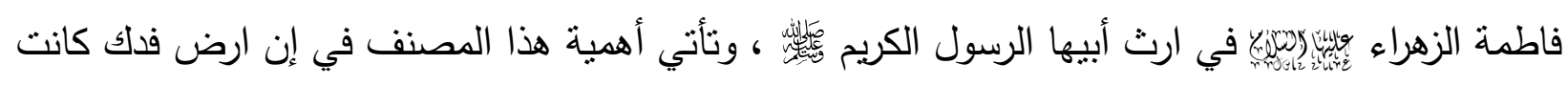

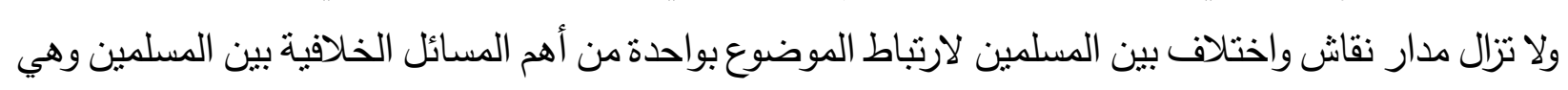

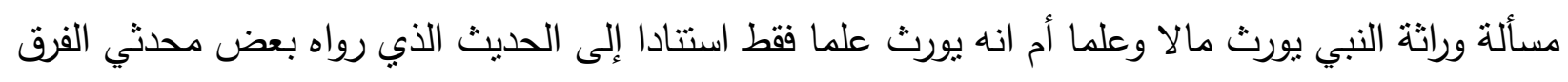

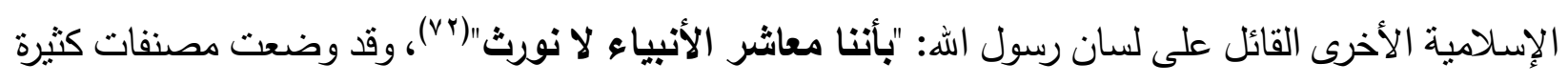

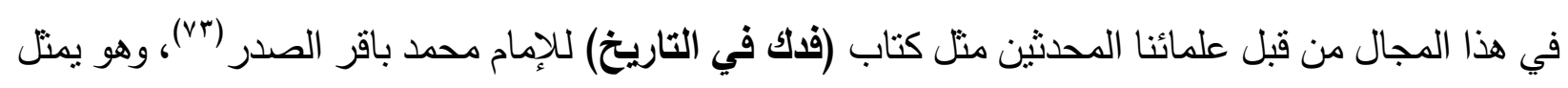
وجهة نظر الإمامية المطلقة في هذا الصدد.

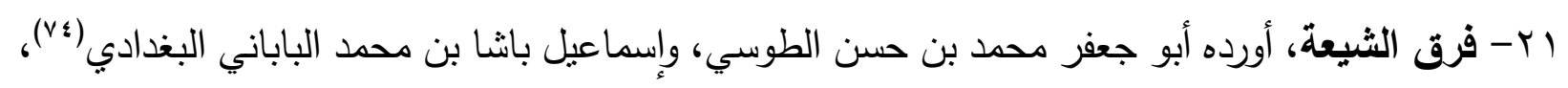
وكما يظهر من العنوان إن المؤلف قصد به البحث عن فرق الثيعة من حيث أماكن نواجدها وانتشارها وكيفية

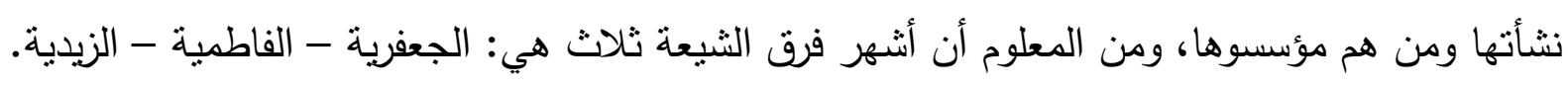
Y Y - مزار أبي عبد الله

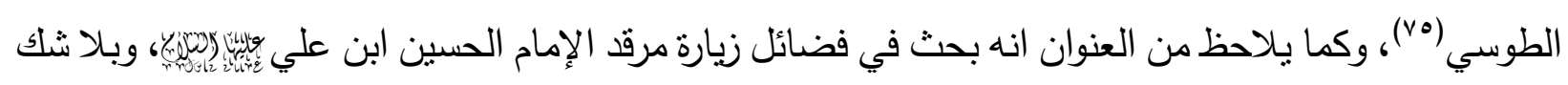

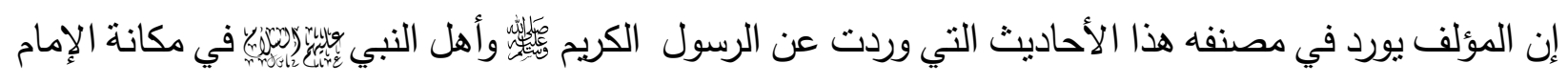

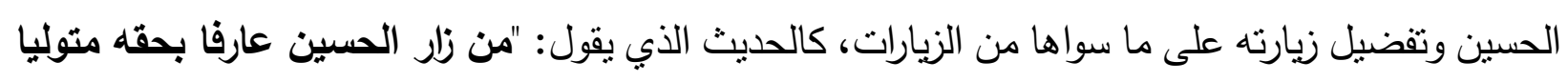

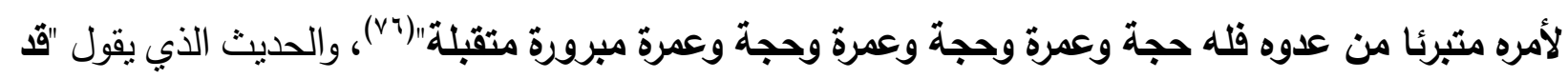

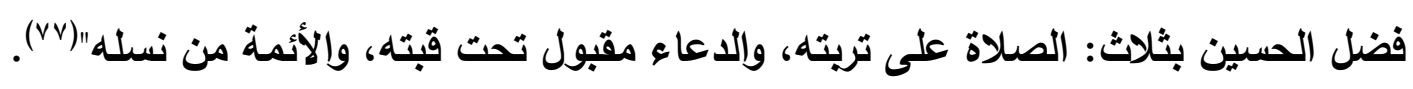

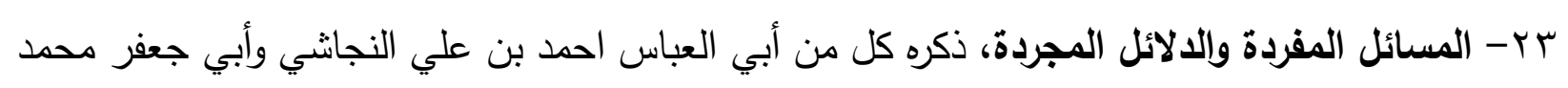

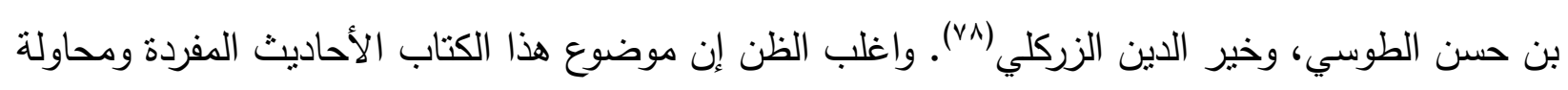

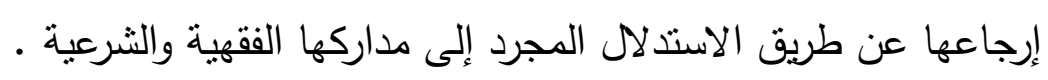

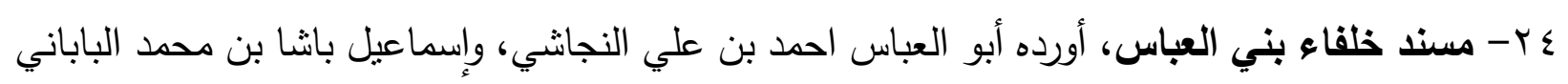
البغدادي(V9). ويبدو انه مجموعة منتخبة من الأحاديث النبوية الثريفة المسندة برواية الخلفاء العباسيين.

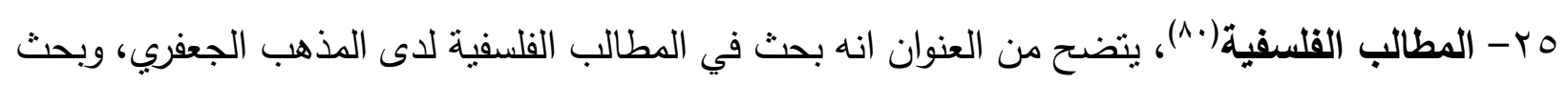

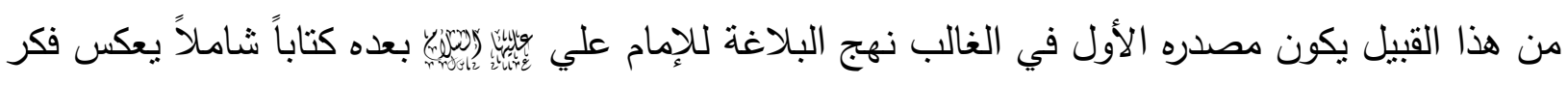

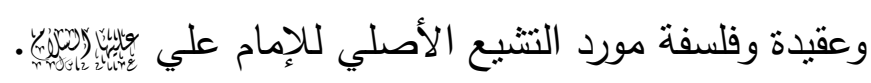

بذللك يكون الثيخ الأنباري قد أبدى في مجمل مصنفاته خدمة جليلة لمن جاء بعده، فقد أسهم في إغناء الفكر

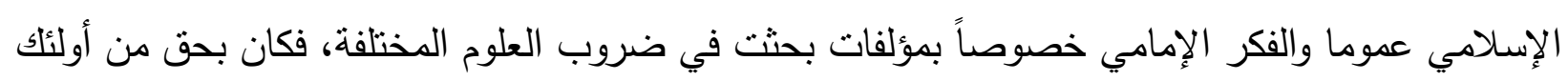
العلماء الذين ركبوا أمواج الفكر الإسلامي الرصين لأهداف إلهية محضة. 
لقد أثناد المؤرخون والعلماء بالثيخ أبي طالب الانباري، ولعل من أبرزهم أبو الفرج بن إسحاق بن النديم

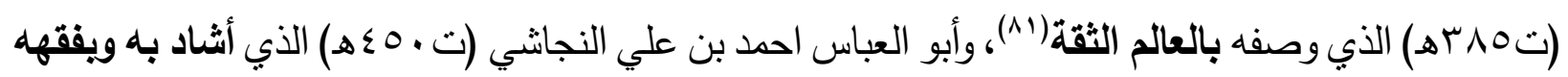

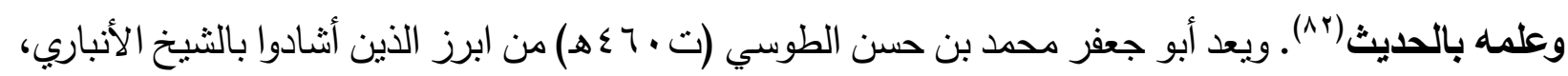

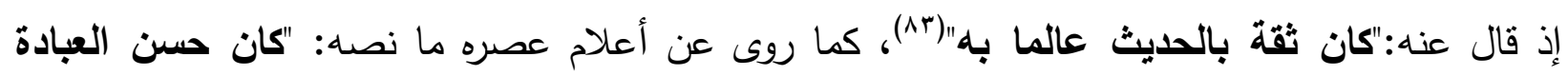

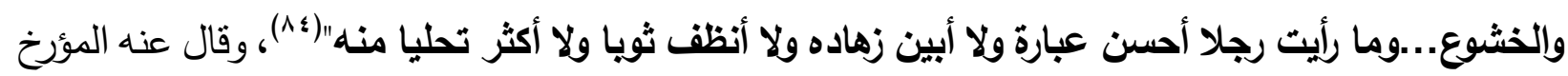

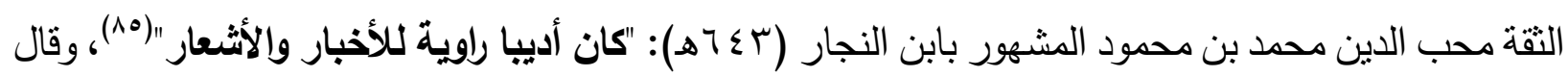

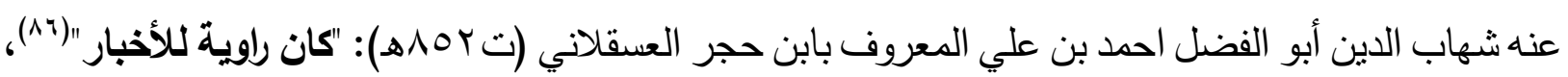

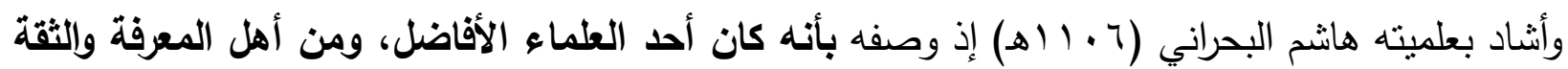

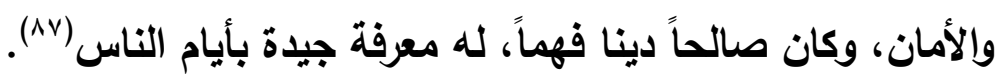
كما أنشاد العلماء والمؤرخون المحدثون بعلمية وصدقية الثيخ الانباري، فقد وصفه عمر رضا كحالة بقوله:

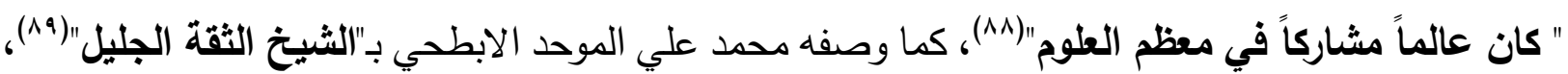

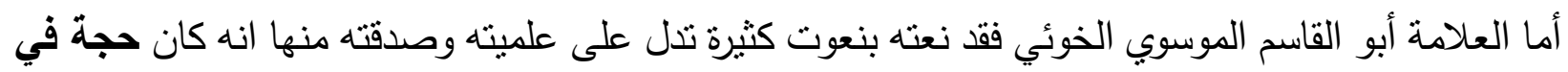

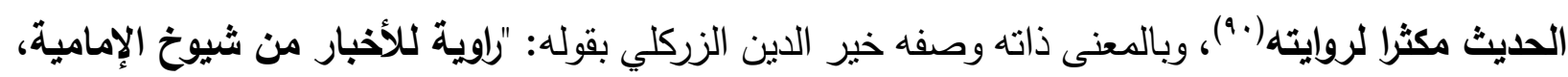
ثقة في الحديث، مكثر من التصانيف"(91). ومما ينقام ينتين لنا بشكل جلي صدق الثيخ أبي طالب الأنباري وتقته في ميدان إملاء العلوم ولا سيما الحديث والفقه الإمامي والتاريخ.

\section{الإنمة}

وخلاصة القول يمكن الوقوف عند النقاط الآتية:

1- كانت واسط مدينة عريقة تزخر بالمؤسسات العلمية والعلماء البارزين في مجال الحديث والفقه والأدب .

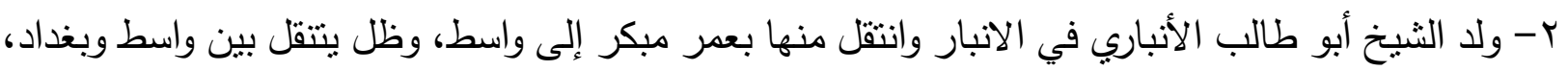

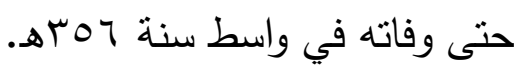
ب- كان الثيخ الأنباري واحداً من أعلام واسط الذين نبغ فهوا في مجال العلوم الدينية، اذ عرف فقيهاً جعفرياً مصنفاً في ذلك جملة من الكتب والرسائل . ع - تميز الثيخ أبو طالب الأنباري بأنه عالم موسوعي على طراز جهابذة العلماء المسلمين فكان فضلاً عن كونه فقيهاً، أديباً وفيلسوفاً. ه- كان الثيخ الأنباري داعية أكثر من كونه فقيهاً تقليدياً بدليل أنه بدءاً لم بيتقر في (بغداد) حاضرة الخلافة

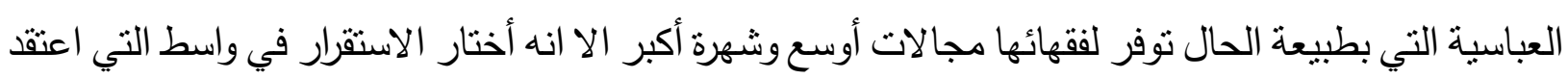
ان وجوده فيها أفضل وأثزه فيها أهم . 
؟- ترك الثيخ الأبباري ما يزيد على المائة والأربعين مصنفاً، حاول في معظمها تسخير علمه للافاع عن المذهب

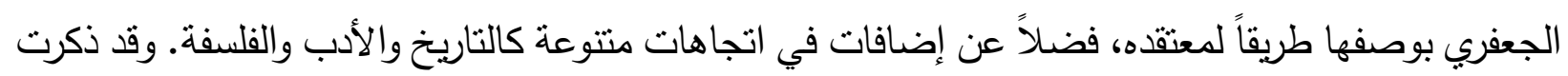
مصادر أخباره خمسة وعشرين مصنفا فقط من مصنفاته.

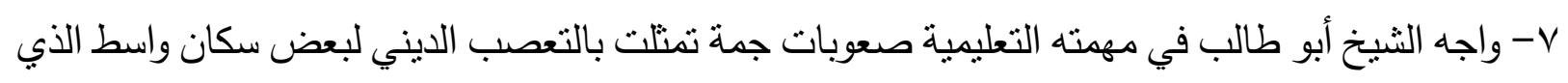

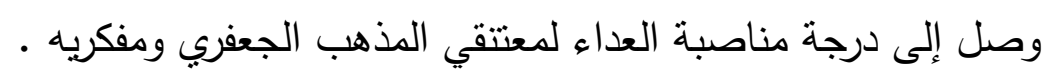

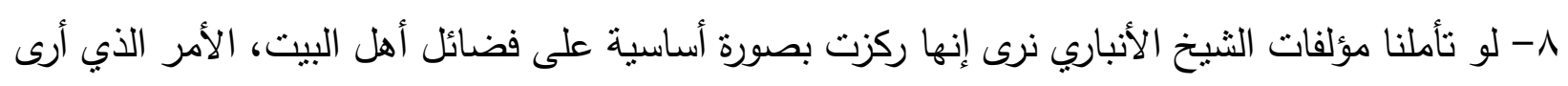

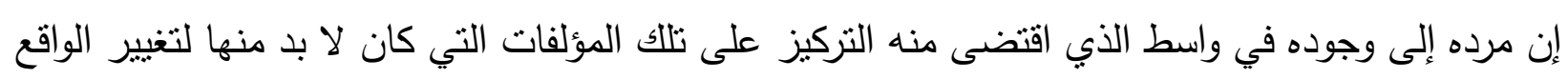
المذهبي لواسط أساساً. 9- أثناد جميع المؤرخين والعلماء الذين ترجموا للثيخ أبي طالب الأنباري بسلوكه القويم وتدينه فضلا عن علمه وتقته في نقل الاخبار وروايتها. • 1- نوصي بتفعيل الدراسات الأكاديمية والبحثية لاعلام الفكر الجعفري لسد الثغرة الكبيرة التي تكتنف المكتبة الأكاديمية من هكذا دراسات.

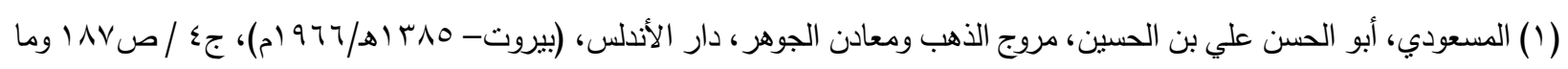

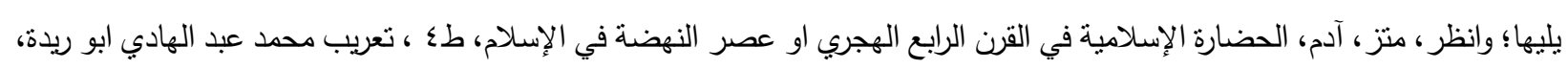

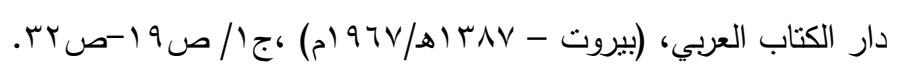
(ץ) ابن الأثير، ابو الحسن عز الدين علي بن محمد، الكامل في التاريخ، طب، تحقيق ابو الفداء عبد الله القاضي، دار الكتب العلمية،

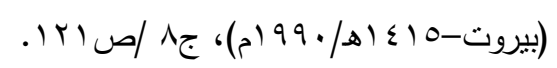

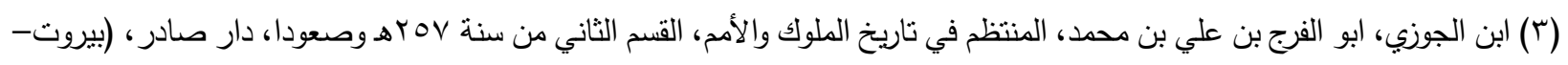

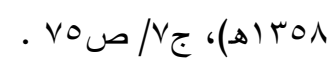

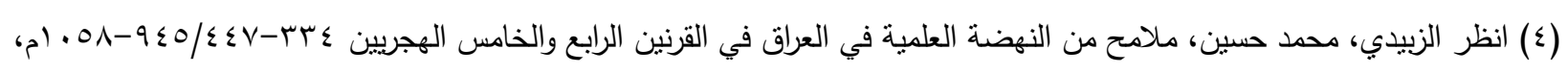

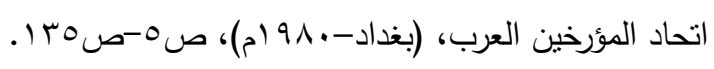

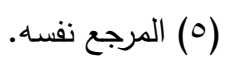

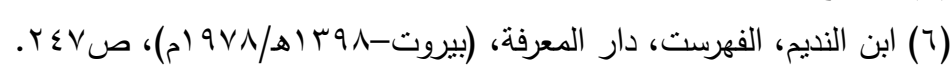

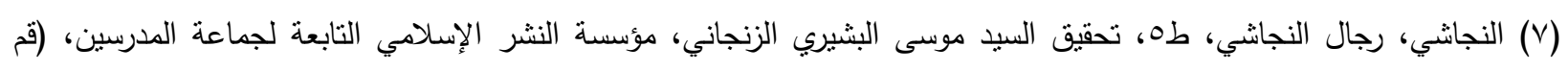

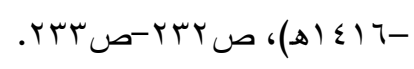

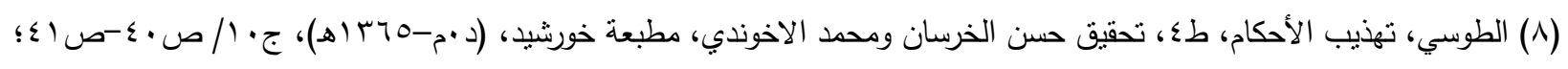

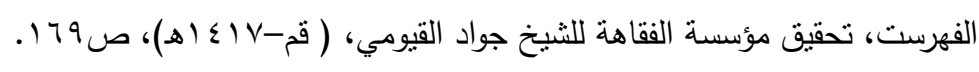

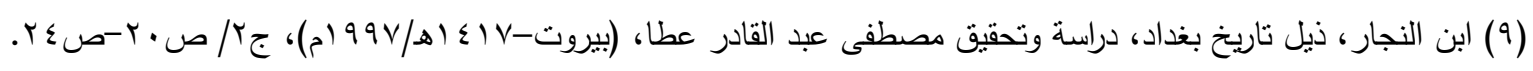

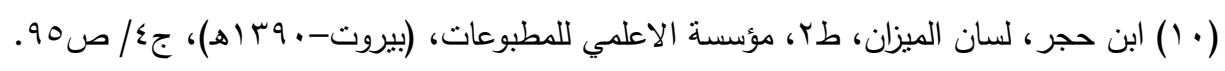

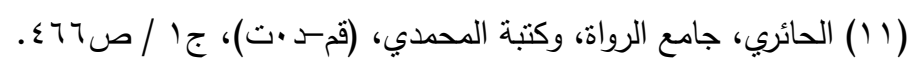

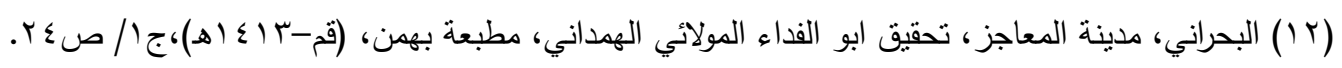

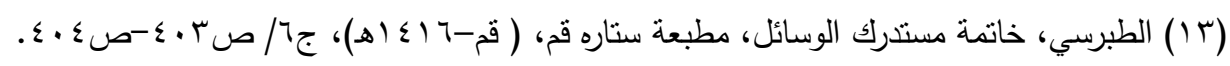




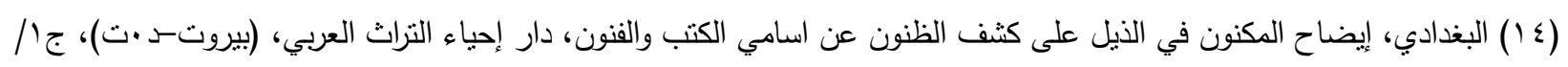
ص • ب إ؛ هدية العارفين أسماء المؤلفين واثار المصنفين، دار إحياء التراث العربي، (بيروت-د •ت) واعادت طبعه بالاوفسيت مكتبة المثنى

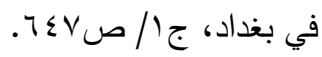

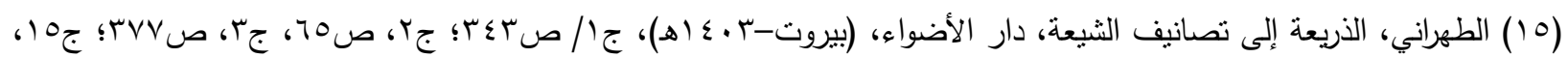

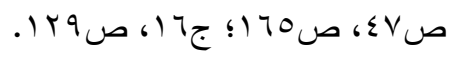

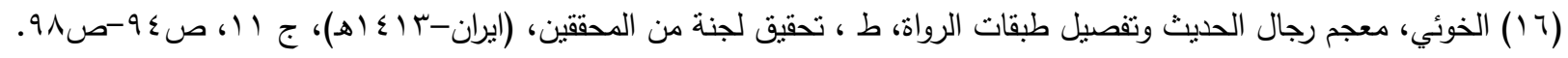

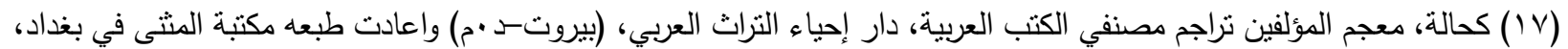

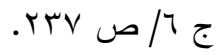

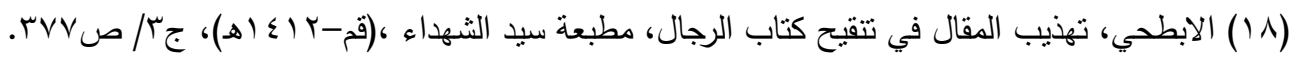

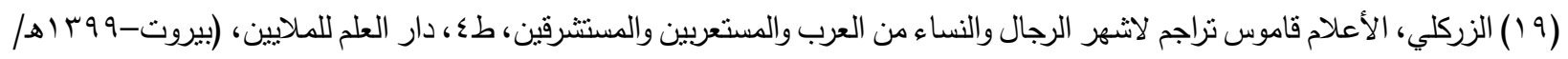

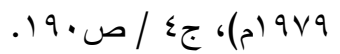

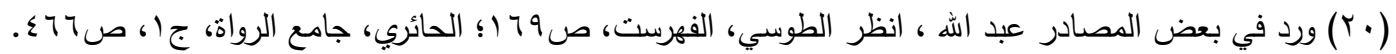

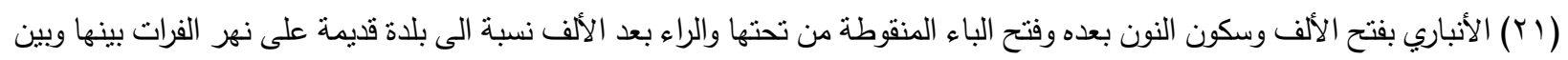

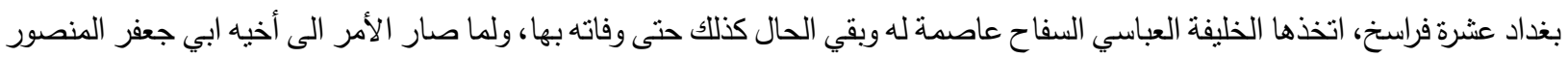
شيد بغداد وانتقل اليها لتكون العاصمة الجديدة للاولة العربية الإسلامية، وقد أنجبت هذه المدينة جماعة من الفضلاء والعلماء بكل فن. انظر :

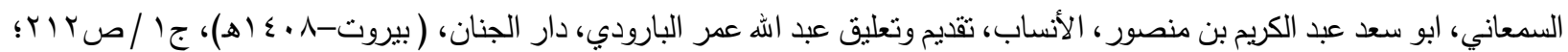

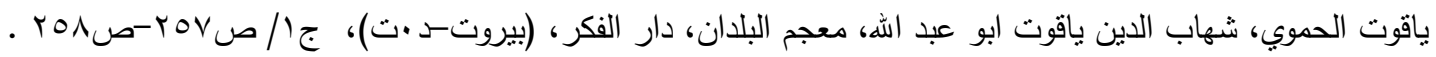

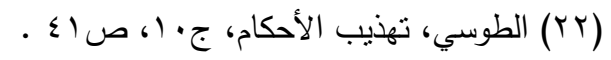

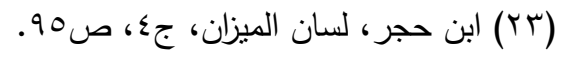

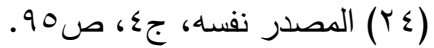

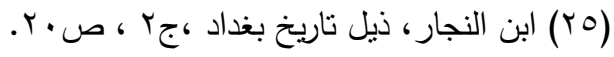

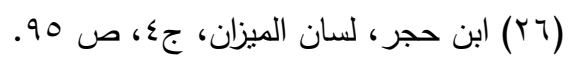
(YV)

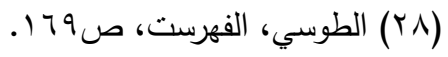

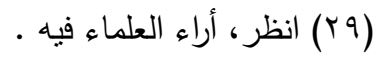

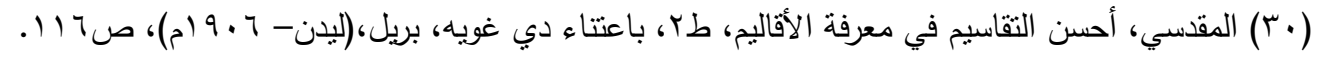

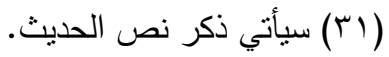

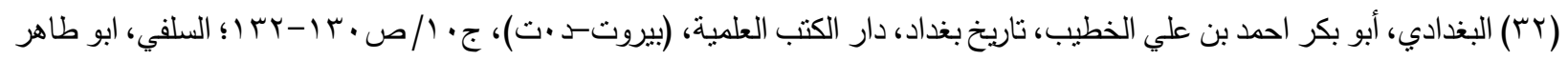

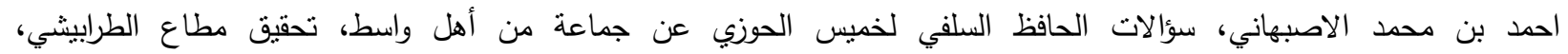

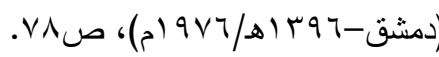

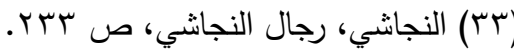

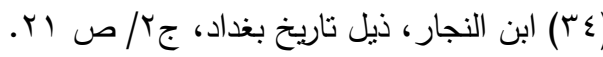

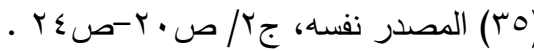

$$
\begin{aligned}
& \text { (דr) المصدر نفسه، جr/ ص זr. }
\end{aligned}
$$

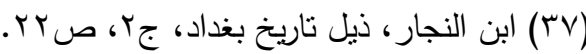

$$
\begin{aligned}
& \text { (r^) (r/) }
\end{aligned}
$$

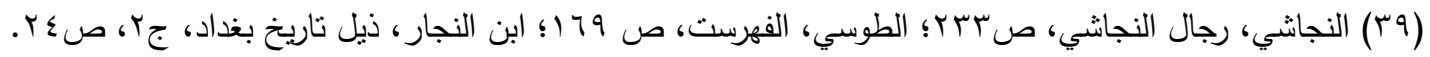
(·ـ) انظر: المعاضيدي، عبد القادر سلمان، واسط في العصر العباسي، دراسة في تتظيماتها الإدارية وحياتها الاجتماعية والفكرية

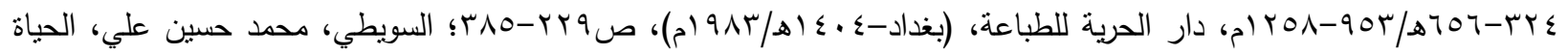


الفكرية في واسط في العصر العباسي، عهد الاستقلال المؤقت ـ09-707هـ، رسالة ماجسنير مقدمة إلى كلية التربية في جامعة واسط لسنة

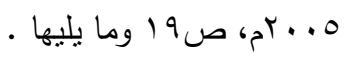

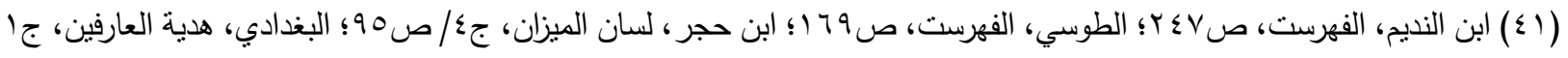

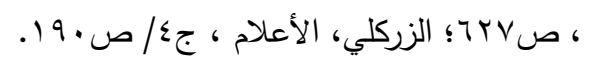

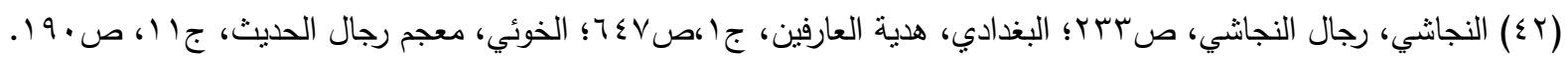

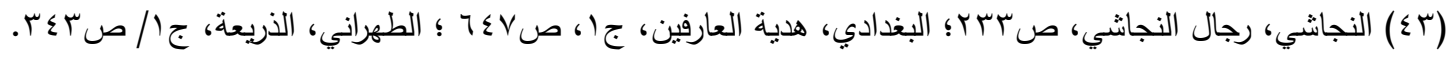

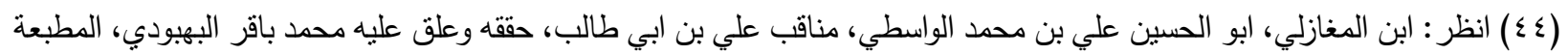

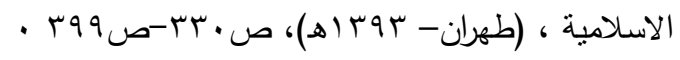

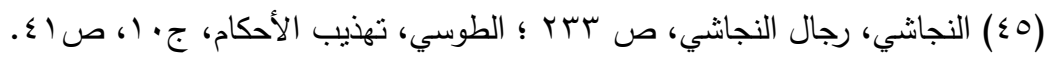

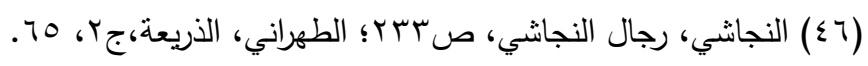

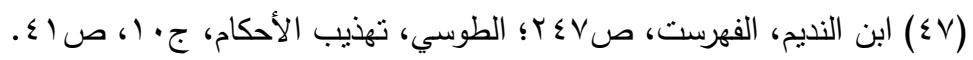

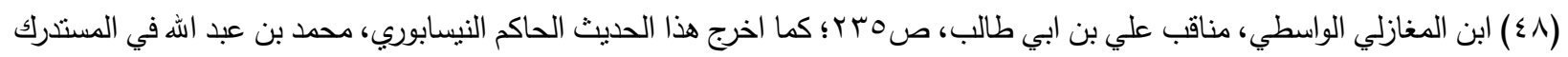

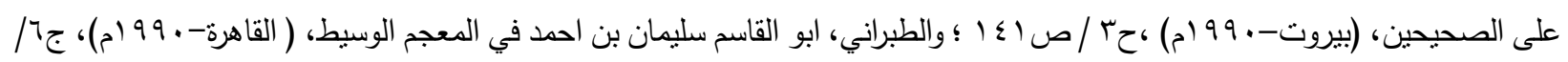
. $9 \cdot 9$

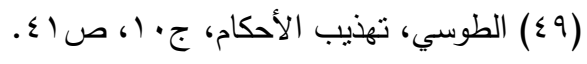

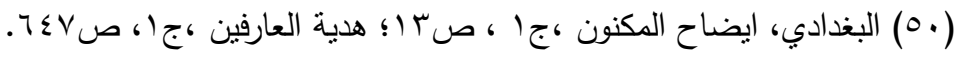

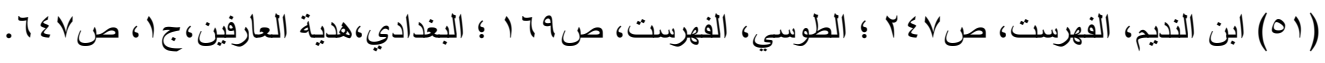
(ro) (ابن الليثي الواسطي، كافي الدين ابن الحسن علي بن محمد، عيون الحكم والمواعظ، تحقيق الثيخ حسين الحسيني البيرجندي، مطبعة

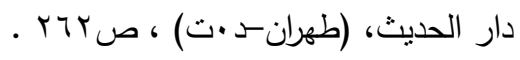

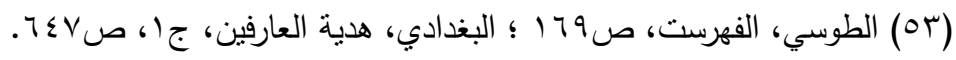

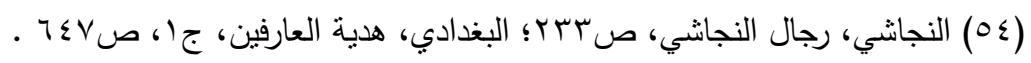

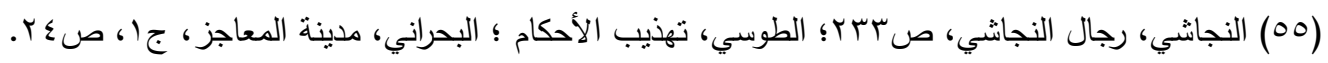

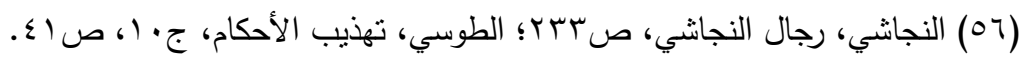

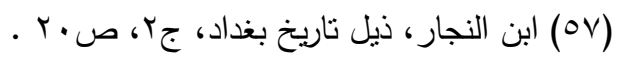

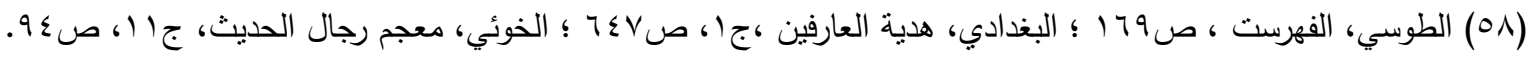

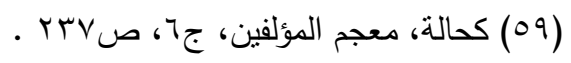

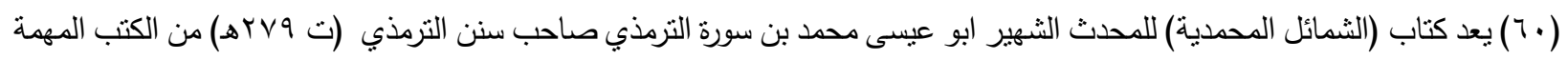

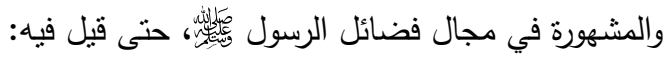

\section{اخلاي إن شط الحبيب وربعه وعز تلاقيه وناعت منازبـهـ. وفاتكم أن تبصروه بعينكم فما فاتكم بالعين هذي شمائلة}

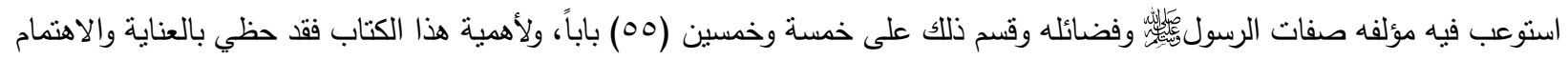

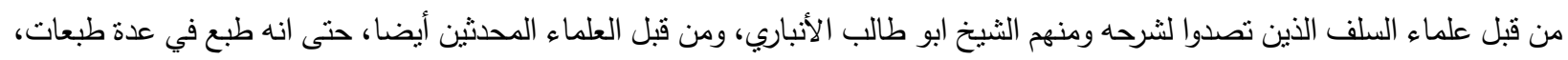

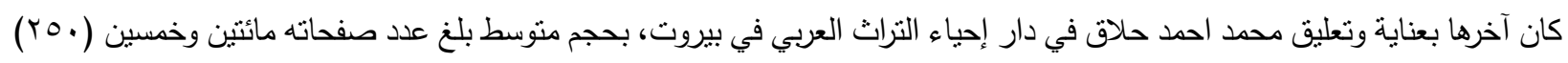

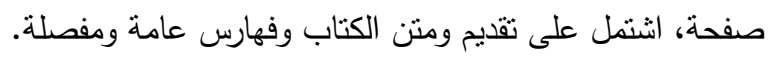

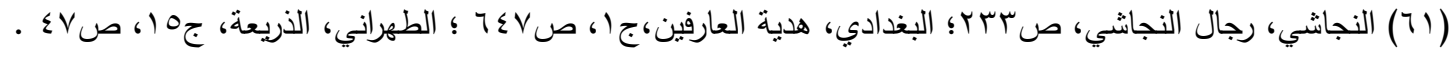

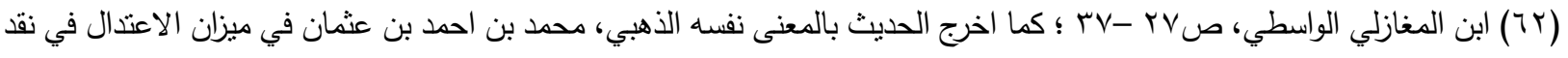

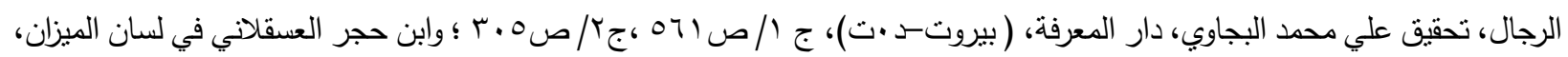

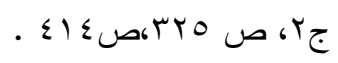




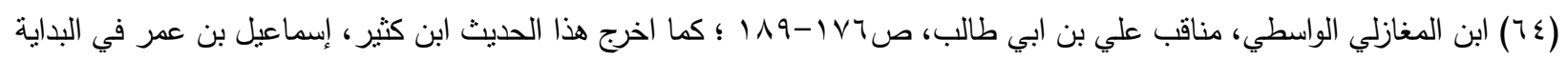

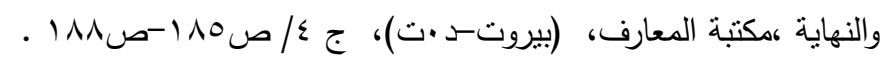

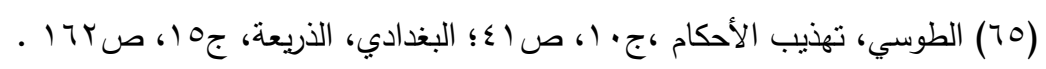

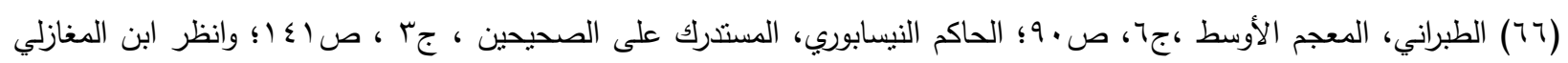

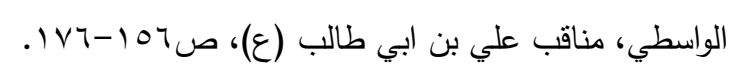

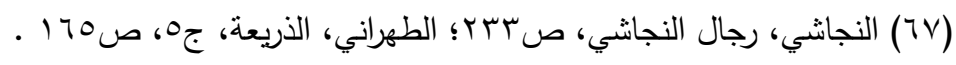

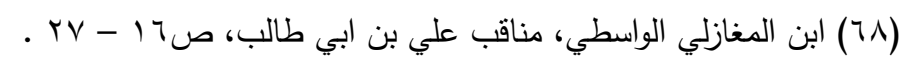

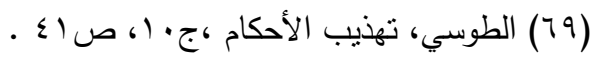

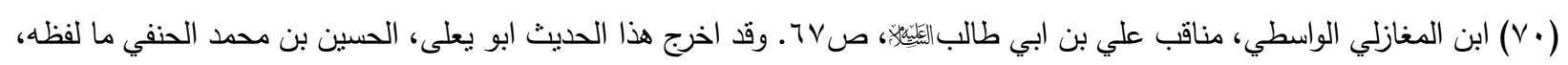

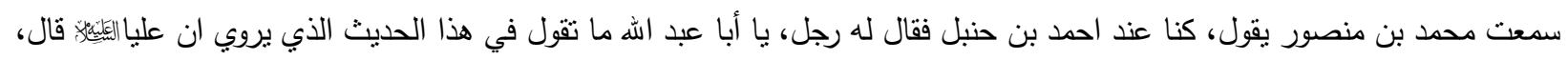

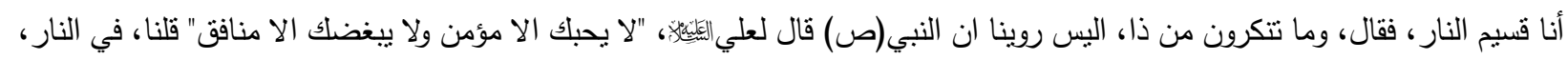

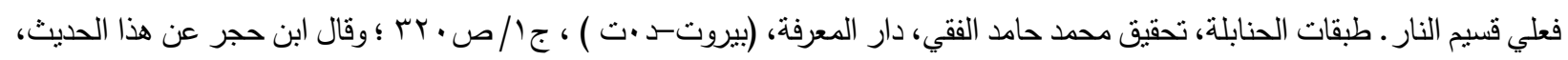

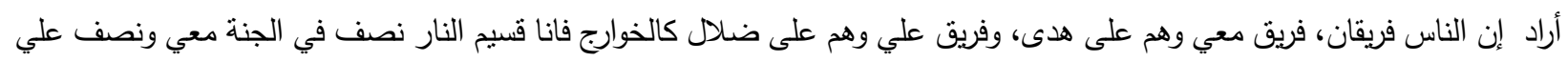

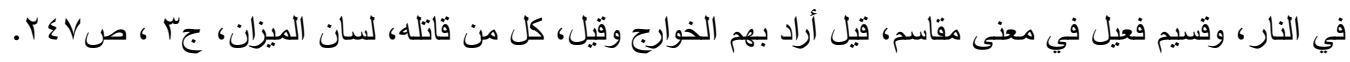

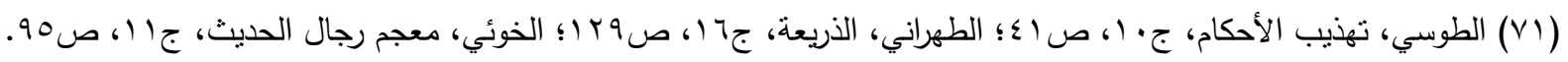

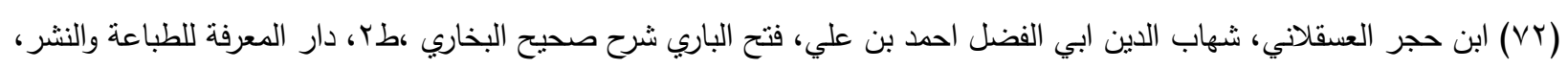

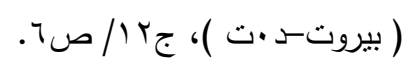

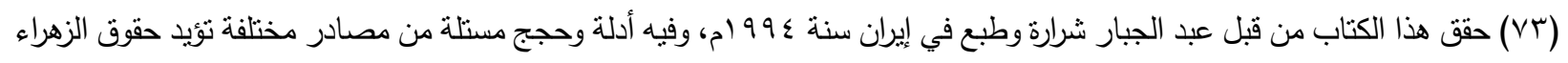

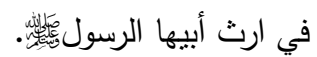

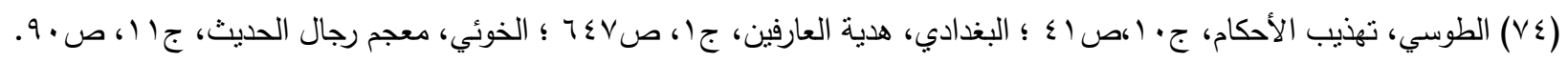

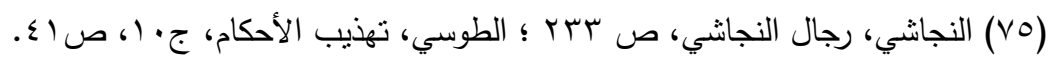

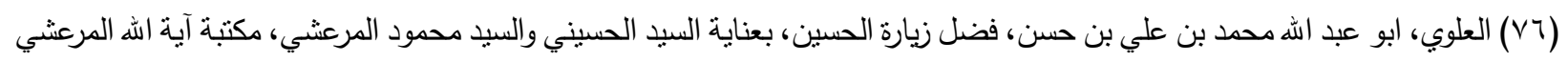

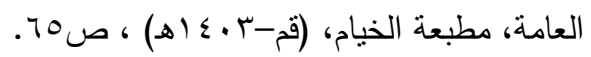
. المصدر نفسه، صع (VV)

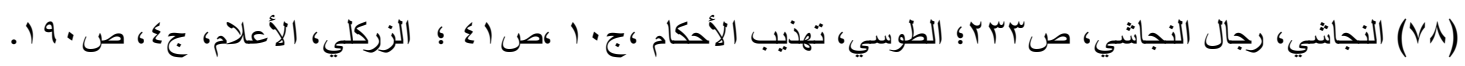

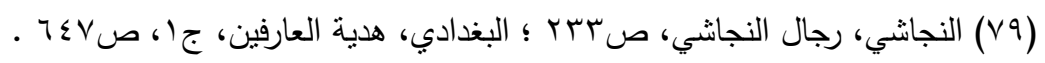

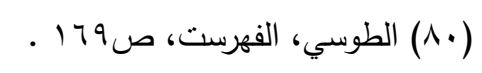

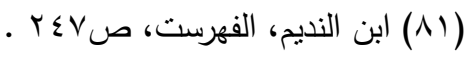

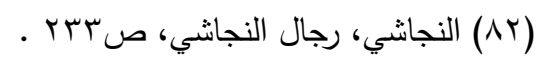

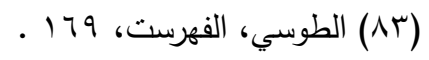

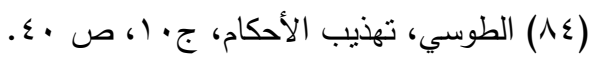

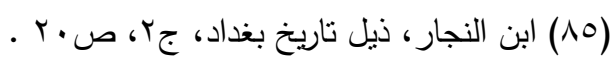

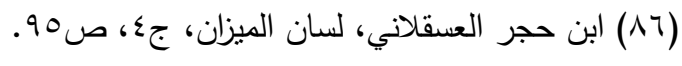

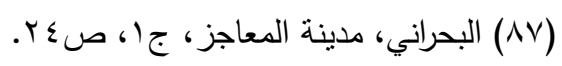

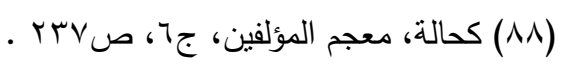

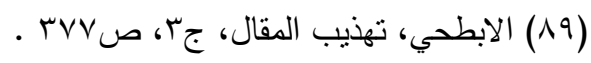

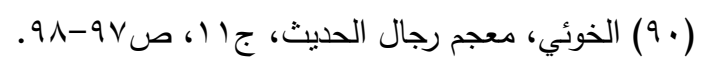

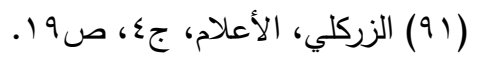




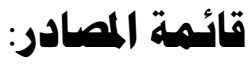

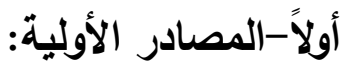

- ابن الأثير، أبو الحسن عز الدين علي بن محمد الثيياني (ت.بآهـ) :

1- الكامل في التاريخ، طن، عدد الأجزاء: .ل، تحقيق أبو الفاء عبد الله القاضي، دار الكتب العلمية،

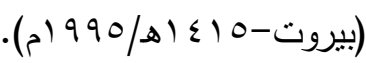

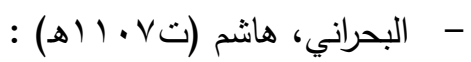

r- مدينة المعاجز، عدد الاجزاء:م ، تحقيق أبو الفداء المولائي الهمداني، مطبعة بهمن ،(قم-ب إ؟ (هـ).

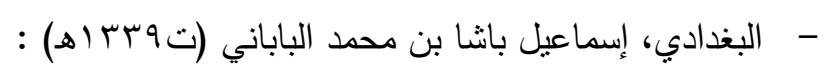

r- ايضاح المكنون في الذيل على كثف الظنون عن اسامي الكتب والفنون، عدد الأجزاء:r، دار إحياء التزاث

$$
\text { العربي، (بيروت-د.ت). }
$$

عـ- هدية العارفين اسماء المؤلفين واثثار المصنفين، عدد الأجزاء:r، دار احياء التزاث العربي، (بيروت -ــت)،

$$
\text { أعادت طبعه بالاوفست مكتبة المثى في بغداد. }
$$

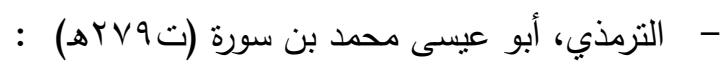

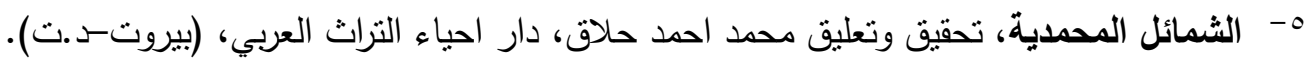

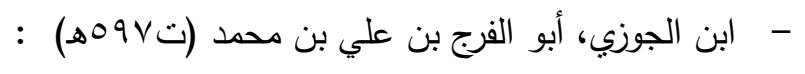

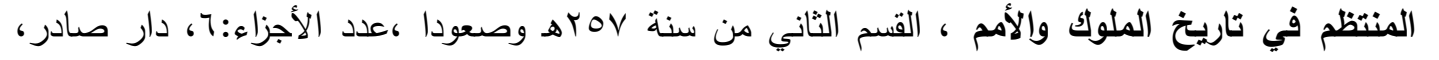

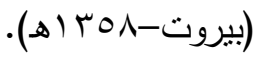

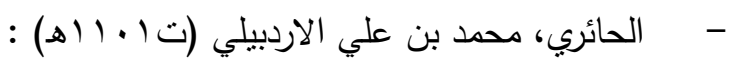

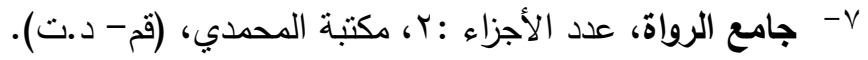

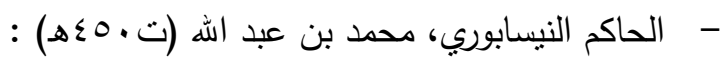

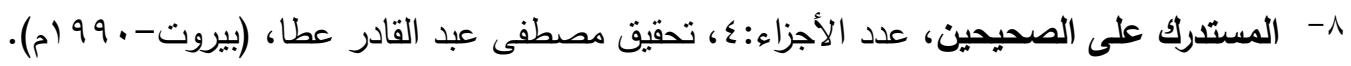

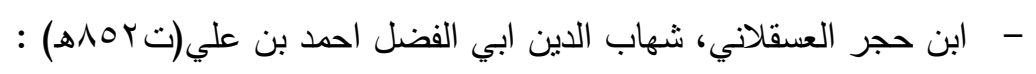

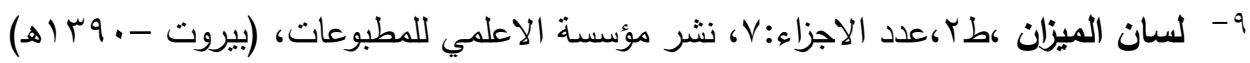

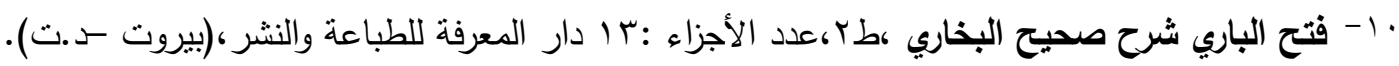

$$
\begin{aligned}
& \text { - الحموي، شهاب الدين ياقوت أبو عبد اله الحموي (ت بrآهـ) : }
\end{aligned}
$$

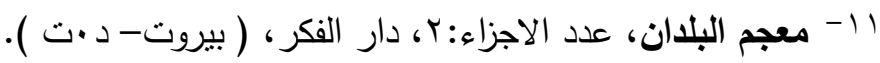

$$
\begin{aligned}
& \text { - - الخطيب البغدادي، أبو بكر احمد بن علي (ت بآكهـ) : }
\end{aligned}
$$

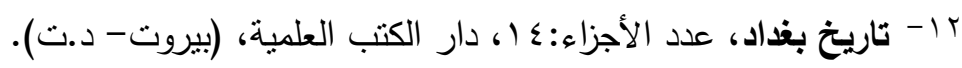

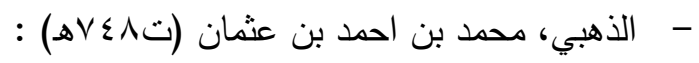

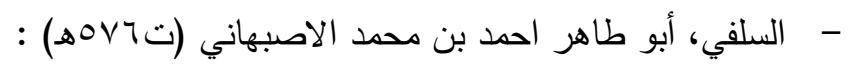

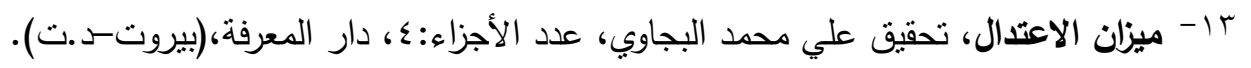

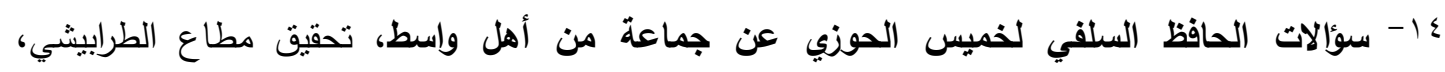

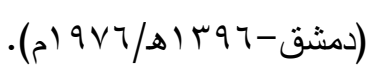

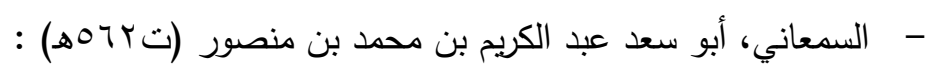

1- الأنساب، تقديم وتعليق عبد اله عمر البارودي، عدد الأجزاء:0، دار الجنان، (بيروت-1، ــ (هـ). 


$$
\begin{aligned}
& \text { - الطبراني، أبو القاسم سليمان بن احمد (ت . بrسه) : }
\end{aligned}
$$

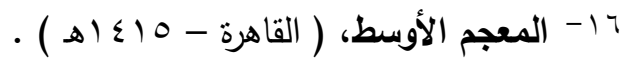

$$
\begin{aligned}
& \text { - - الطبرسي، النوري (ت • ب آهـ) : }
\end{aligned}
$$

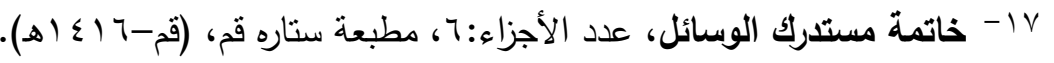

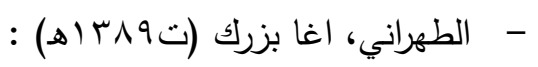

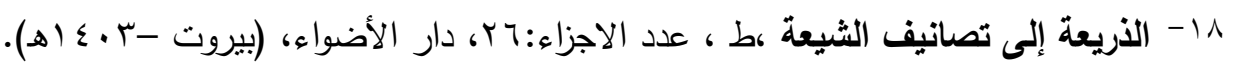

$$
\text { - الطوسي، أبو جعفر محمد بن الحسن (ت . بــهـ) : }
$$

تهذيب الاحكام، طع، عدد الأجزاء : •(اكتحقيق حسن الخرسان ومحمد الاخوندي، مطبعة خوشيد،

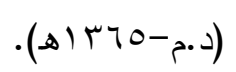

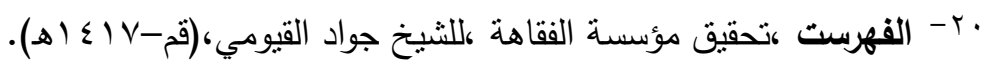

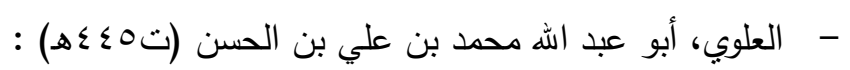

اب- فضل زيارة الحسين،بعناية السيد الحسيني والسيد محمود المرعشي مكتبة آية اله المرعشي العامة ،مطبعة

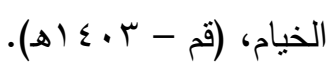

-

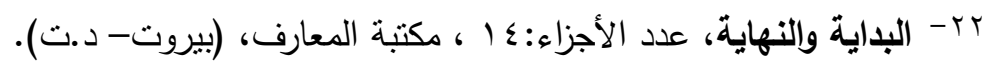

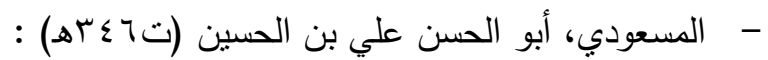

rץ- مروج الذهب ومعادن الجوهر ،عدد الأجزاء:ء؛، دار الأندلس، (بيروت-

- - ابن الليثي الواسطي، كافي الدين ابن الحسن علي بن محمد(ت في القرن السادس الهجري)

ع ז- عيون الحكم والمواعظ، تحقيق الثيخ حسين الحسيني البيرجندي، مطبعة دار الحديث ،طهران -ـــت).

$$
\text { - - ابن المغازلي الواسطي، أبو الحسن علي بن محمد (ت مبحگهـ) : }
$$

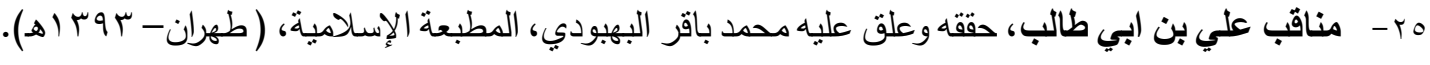

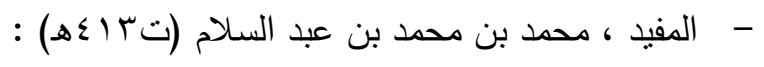

بr- الإرشاد في معرفة حجج الله على العباد، تحقيق مؤسسة ال البيت، عدد الأجزاء:r، دار المفيد، ( ايران-

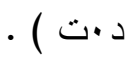

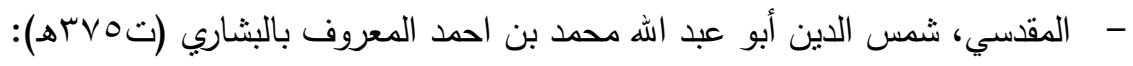

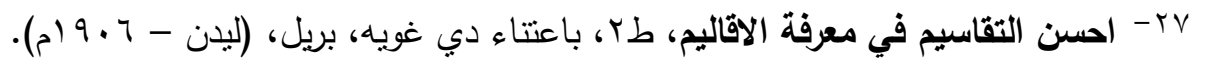

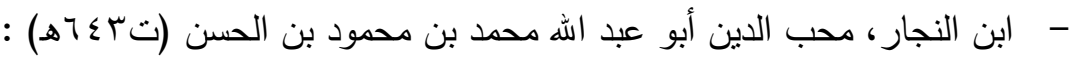

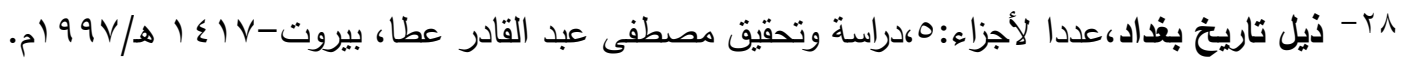

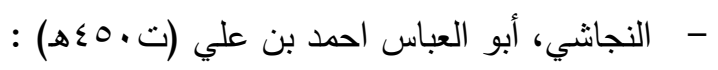

9r- رجال النجاشي، طه ،تحقيق السيد موسى البشيري الزنجاني، مؤسسة النشر الإسلامي التابعة لجماعة

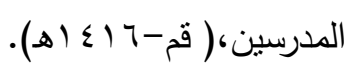

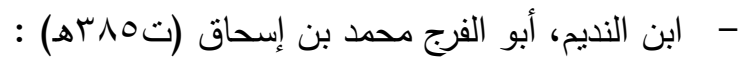

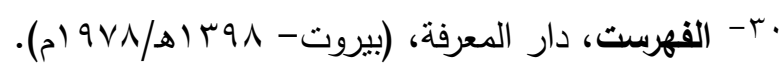

- أبو يعلي، أبو الحسين محمد (ت ب ا0هـ) :

ابr- طبقات الحنابلة، تحقيق محمد حامد الفقي، دار المعرفة،(بيروت - د.ت). 


$$
\text { - ثانياً - المراجع الثانويةة: }
$$

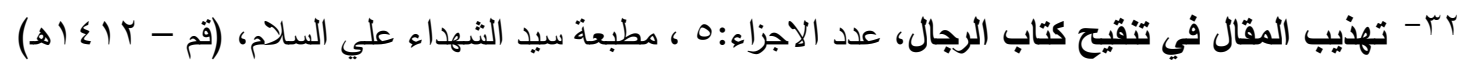

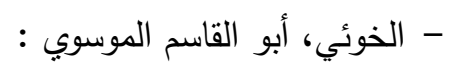

-rr- معجم رجال الحديث وتفصيل طبقات الرواة، طه، عدد الاجزاء:؟ ب، تحقيق لجنة من المحققين، ( ايران -

(ه)

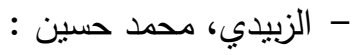

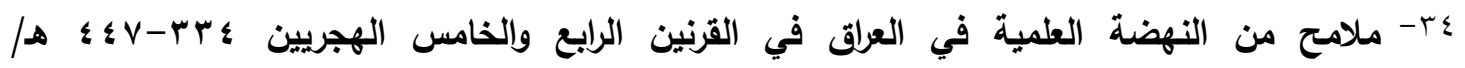

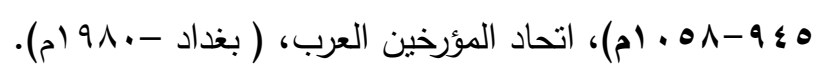

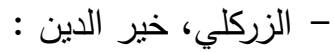

مr- الأعلام، قاموس تراجم لأثهر الرجال والنساء من العرب والمستعرين والمستشرقين، طع، دار العلم

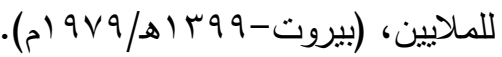

$$
\begin{aligned}
& \text { - السوبطي، محمد حسين علي: }
\end{aligned}
$$

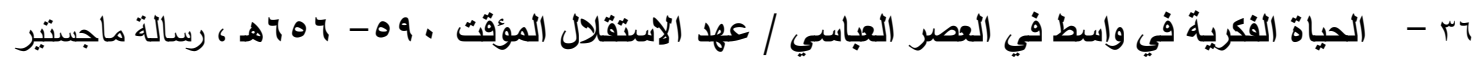

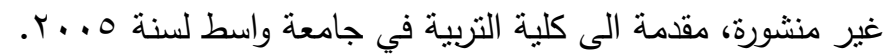

-

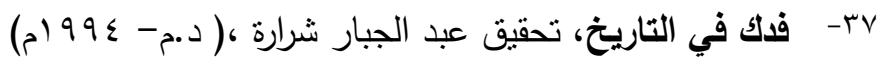

- كحالة، عمر رضا:

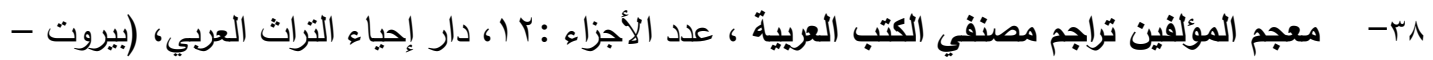

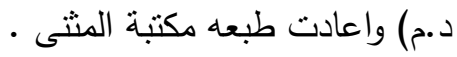

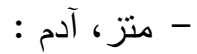

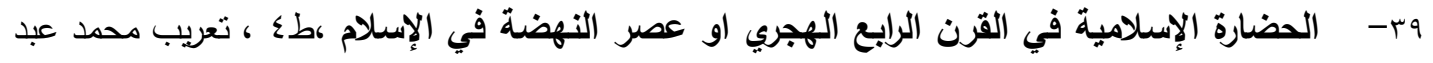

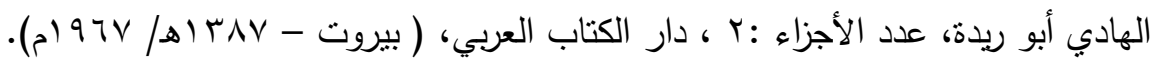

- المعاضيدي، عبد القادر سلمان :

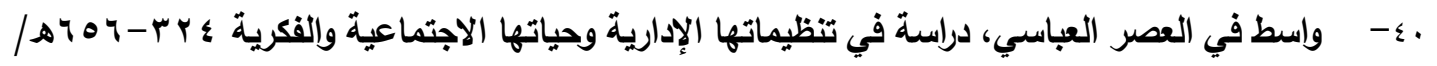

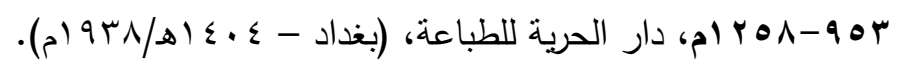

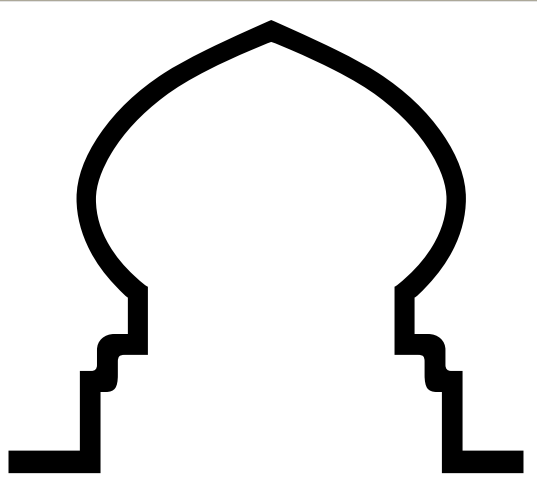


